\title{
The Current Status of the World Nuclear Industry
}

\author{
Mycle Schneider, and Antony Froggatt ${ }^{1}$
}

\section{Abstract}

The following chapter is based on the World Nuclear Industry Status Report 2018 (WNISR2018). The annual WNISR is a comprehensive assessment of the status and trends of the global nuclear power industry.

\section{Introduction}

Heat. The planetary, record-breaking heatwave in 2017 gave a daunting hint on what the future on earth will almost certainly look like.

Water. The food system is the most sensitive to lack of water. As of early August 2017 , it is already clear that the draught will severely impact harvests in many parts of the world.

1 Mycle Schneider, International Analyst on Energy and Nuclear Policy, Paris, France, mycle@sfr.fr; Antony Froggatt, Chatham House, London, United Kingdom, afroggatt@ chathamhouse.org.uk

(C) The Author(s) 2019

R. Haas et al. (Eds.), The Technological and Economic Future

of Nuclear Power, Energiepolitik und Klimaschutz. Energy Policy 
Heat, water and nuclear power. Thermal power plants need vast amounts of cooling water. It is estimated that in France 51 percent of freshwater takeout or about 10 percent of precipitation is absorbed in thermal power plants, with roughly three-quarters of its electricity generated by nuclear power over the years. No other electricity generating source needs more water than atomic fission energy. David Lochbaum, Director of the Nuclear Safety Project at the Union of the Concerned Scientists (UCS), who has produced a fact sheet on "Nuclear Power and Water"2, stated: "We'll have to solve global warming if we want to keep using nuclear power"."

The European Pressurized Water Reactor (EPR) under construction at Flamanville on the coast of Normandy will have its own desalination plant to cope with freshwater needs. Four in-land reactor sites along French rivers with no cooling towers-Bugey ( 2 units), Fessenheim ( 2 units), St. Alban (2 units), Tricastin (4 units)-take out about 70 percent of all thermal power plant cooling water in the country. The two oldest French reactors at Fessenheim alone take up about 18 percent of all 17 billion cubic meters of France's annual freshwater takeouts. ${ }^{4}$ While these sites consume a large portion of the nation's surface freshwater, they return about 90 percent back to the environment, but significantly heated up.

And that is a problem. In order to make sure reactors can be appropriately cooled, the uptake water temperature is limited for safety reasons, and to avoid excessive heating of the rivers, the operating licenses impose limits to downstream water temperatures. Consequently, as of 1 August 2018, operators in several countries, including Finland, France, Germany, Sweden and Switzerland, had put operational restrictions on some of their nuclear power plants. While in most cases, regulations required to lower the output of the reactors by 10 percent or so, some reactors were shut down, including at least four reactors in France, to deal with the problem.

The heat symptom occurred just after the first EPR (European Pressurized Water Reactor) and the first AP1000 had started up within 24 hours interval-both in China-end of June 2018. A shift towards better times for the global nuclear industry? By no means. On every piece of positive development follows an avalanche of bad news. For now, the heat wave is only a secondary problem for the industry.

2 UCS, “Nuclear Power and Water”, 2011, see https://www.ucsusa.org/sites/default /files/1 egacy/assets/documents/nuclear_power/fact-sheet-water-use.pdf accessed 2 August 2018.

3 Commons, "Amid climate concerns, nuclear plants feel the heat of warming water", Energy News Network, see https://energynews.us/2016/09/09/midwest/nuclear-plantsfeel-the-heat-of-warming-water/ accessed 1 August 2018.

4 CGDD, "Les prélèvements d'eau par usage et par ressource", 21 June 2017, see http://www. statistiques.developpement-durable.gouv.fr/lessentiel/ar/234/1108/prelevements-deau-usage-ressource.html accessed 1 August 2018. 
The general malaise about the uncertain future of the industry remains deep and disconcerting.

While China proudly presents the prowess of its construction industry with the completion of the first Generation-III reactors-designed by western companies, the EPR by Framatome-Siemens and the AP1000 by Westinghouse, the now-bankrupt worldwide largest historic builder - the rest of the world wonders at what rhythm the country will continue to expand its nuclear program. No new commercial reactor construction was launched in China since December 2016.

In France, the sub-standard pressure vessel of the Flamanville EPR was declared fit to operate by the safety authority, but the vessel head will have to be replaced after only six years of operation. Startup was delayed again by several months after numerous faulty welds were identified in the main steam supply system. After the technical bankruptcy, subsequent government bailout, breakup and name-change of AREVA to Orano, the new company renews with the old pattern and has been losing money again in 2017.

In Japan, the utilities managed to increase the number of operating reactors from zero in 2014 to nine by mid-2018. But this remains a very limited success with the plants contributing just 3.6 percent of the national electricity generation and 26 reactors remaining in Long-Term Outage (LTO, see definition below). Local populations and the general public remain overwhelmingly opposed to the restart of reactors. The attempts of the Japanese government to declare certain Fukushima evacuation zones as "decontaminated" and suitable for return did not convince many evacuees and most of them will likely never go back.

In the United Kingdom (U.K.), the Hinkley Point C project is underway but strangely still not officially under construction. After having spent at least $€ 3$ billion and thousands of workers on-site, apparently, the base-mat of the reactor building has still not being concreted - that marks the official construction start. Latest news on new-build in the U.K. is that Toshiba-former owner of Westinghouse-has stripped Korea Electric Power Company (KEPCO) of the preferred bidder status to acquire 100 percent of the company NuGen set up to build a nuclear power plant at the Moorside site in Cumbria. ${ }^{5} \mathrm{KEPCO}$ had been seen as the most promising candidate for the takeover, after other potent potential investors like the French Engie or Spanish Iberdrola left the U.K. new-build playing field. Toshiba got severely burnt in the Westinghouse bankruptcy and will not build any reactors any more. Prof. John Loughhead, Chief Scientist at the Business, Energy and Industrial Strategy

5 WNN, "Kepco loses preferred bidder status for NuGen", 1 August 2018, see http://www. world-nuclear-news.org/Articles/Kepco-loses-preferred-bidder-status-for-NuGen, 2 August 2018. 
Ministry (BEIS), stated at a conference at the UK Royal Society on "Decarbonising UK energy": "There are clear issues with nuclear technology at present. The nuclear industry has created a product so expensive that no one can afford to buy it."

In the United States (U.S.)., many reactors remain threatened to shut down long before their licenses expire because they cannot compete in the market. The nuclear industry and its supporters are clearly now focusing on efforts to come up with innovative subsidizing schemes, in particular on state level, to help avoiding "early closures" of uneconomic reactors. Science Daily titles a research paper?: "The vanishing nuclear industry" and is asking: "Could nuclear power make a significant contribution to decarbonizing the US energy system over the next three or four decades?", only to provide the answer: "Probably not." In May 2018, William Von Hoene, Senior Vice President and Chief Strategy Officer with Exelon, the largest nuclear operator in the U.S., had this to say: “I don't think we're building any more nuclear plants in the United States. I don't think it's ever going to happen... They are too expensive to construct, relative to the world in which we now live." 7 The recent revelation by the Wall Street Journal is therefore barely surprising: "A major donor to President Trump agreed to pay US $\$ 10$ million to the president's then-personal attorney if he successfully helped obtain funding for a nuclear-power project, including a $\$ 5$ billion loan from the U.S. government..." The project in question is the Bellefonte plant in Tennessee, where the construction of two reactors was launched in the 1970s and abandoned in the 1980s-two of 42 nuclear construction sites abandoned in various stages of advancement in the U.S. alone. In 2016, the site was purchased by a private company for US $\$ 111$ million with the stated-intention to invest up to US $\$ 13$ billion to complete construction. Obviously, the project needed government support, as everywhere else, thus the willingness to pay President Trumps long-time fixer the extraordinary amount of US $\$ 10$ million to help obtain a government loan.

Nuclear new-build is simply not competitive under ordinary market economy rules anywhere. Worse, like in the U.S., similar economic constraints continue to

6 David Lowry, personal communication, 4 October 2017.

7 Science Daily, “The vanishing nuclear industry”, ScienceDaily, 2 July 2018, see https:// www.sciencedaily.com/releases/2018/07/180702154736.htm, accessed 7 July 2018.

8 With 23 operational reactors, Exelon is the US' largest nuclear operator. S\&P Global Platts, "No new nuclear units will be built in US due to high cost: Exelon official", 18 April 2018, see https://www.platts.com/latest-news/electric-power/washington/no-newnuclear-units-will-be-built-in-us-due-26938511, accessed 22 May 2018.

9 WSJ, “Top Trump Donor Agreed to Pay Michael Cohen \$10 Million for Nuclear Project Push”, 2 August 2018, see https://www.wsj.com/articles/top-trump-donor-agreed-to-paymichael-cohen-10-million-for-nuclear-project-push-sources-say-1533245330, accessed 3 August 2018. 
press owners of currently operating, amortized reactors around the world, leading to an increasing number of units being closed permanently earlier than anticipated.

Finally, maybe the largest barrier to nuclear power development or its mere survival is still the time factor. The German electrical and electronics giant Siemens has just raised the stakes to an unprecedented level. In June 2018, Siemens connected 14.4 GW of turnkey natural gas combined cycle power capacity to the grid in Egypt 27.5 months aft construction start, three years after contract signature, boosting the national electricity generating capacity by 45 percent. An intermediate step of $4.8 \mathrm{GW}$, the first of the three giant plants, started up after only 18 months. With over 60 percent efficiency, these combined-cycle gas plants are almost twice as efficient as nuclear reactors. The next step is the implementation of up to 600 wind turbines with a total capacity of up to $2 \mathrm{GW}$, part of the goal of $7.2 \mathrm{GW}$ wind power capacity spinning by $2020 .^{10}$

\section{General overview worldwide}

\section{The role of nuclear power}

As of mid-2018, 31 countries were operating nuclear power reactors. That number has remained stable since Iran started up its first reactor in 2011.

The world nuclear fleet generated 2,503 net terawatt-hours (TWh or billion kilowatt-hours) of electricity in $2017^{11}$, a one percent increase, but still less than in 2001 and four percent below the historic peak nuclear generation in 2006 (see Figure 1). Without China-which increased nuclear output by 35 TWh (+18 percent), more than the worldwide increase of $26 \mathrm{TWh}$-global nuclear power generation would have slightly decreased again in 2017. This is the third year in a row that China alone made up for the global decrease outside the country. In fact, in the past decade, only three years would have seen a global increase without China, 2010, 2013 and 2014, the year before 3/11 triggered the Fukushima disaster, and the two years after the $284 \mathrm{TWh}$ (11 percent) production slump in 2011-2012.

10 Siemens, "Completion of world's largest combined cycle power plants in record time", 24 July2018, seehttps://www.siemens.com/press/en/feature/2015/corporate/2015-06-egypt. php accessed 2 August 2018.

11 If not otherwise noted, all nuclear capacity and electricity generation figures based on International Atomic Energy Agency (IAEA), Power Reactor Information System (PRIS) online database, see http://www.iaea.org/programmes/a2/index.html. Production figures are net of the plant's own consumption unless otherwise noted. 


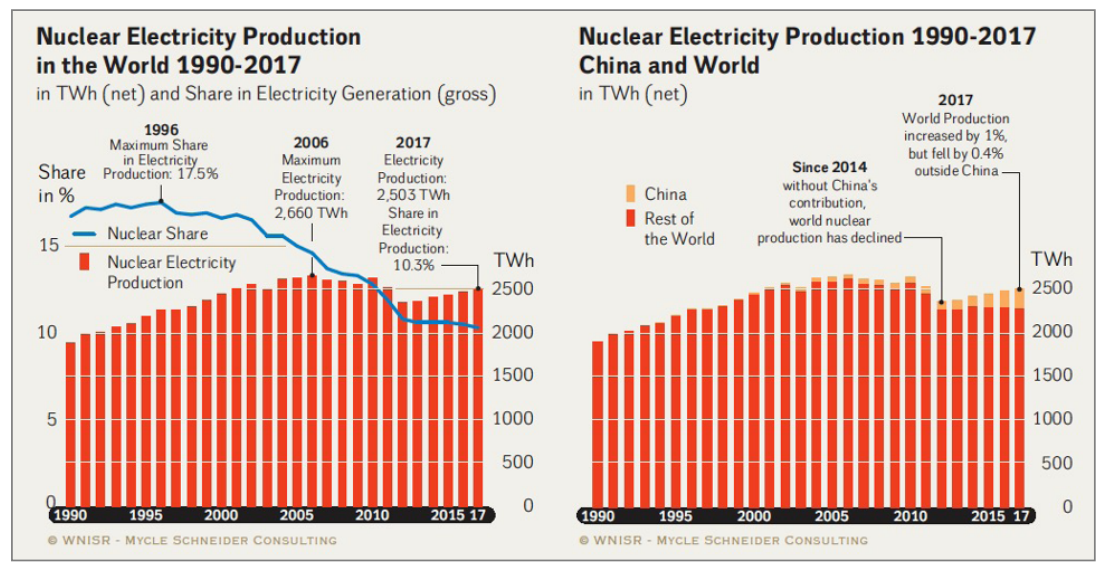

Fig. 1 Nuclear Electricity Generation in the World... and China Sources: WNISR, with IAEA-PRIS, 2018, p. 28

Close to half of the world's nuclear power countries are located in the European Union (EU), and, in 2017, they accounted for 31.5 percent of the world's gross nuclear production, with half of the EU generation in France.

Nuclear energy's share of global commercial gross electricity generation remained almost stable over the past five years $(-0.5$ percent over the period), after dropping below 11 percent in 2012, for the first time in over three decades. The nuclear share declined slowly but steadily from a peak of about 17.5 percent in 1996 to 10.3 percent in 2017. Nuclear's primary energy remained rather stable after hitting a 30-year low at 4.4 percent in $2014 .^{12}$

In 2017, nuclear generation increased in 13 countries, declined in 11, and remained stable in seven. ${ }^{13}$ Five countries (China, Hungary, Iran, Pakistan, Russia) achieved their greatest lifetime nuclear production in 2017. Of these, China and Pakistan connected new reactors to the grid. China started up three units, and Chinese companies built the one that was commissioned in Pakistan.

As in previous years, in 2017, the "big five" nuclear generating countries-by rank, the United States, France, China, Russia and South Korea-generated 70 percent

12 BP, “Statistical Review of World Energy 2017”, June 2018, see https://www.bp.com/ content/dam/bp/en/corporate/pdf/energy-economics/statistical-review/bp-stats-review2018-full-report.pdf accessed 28 July 2018.

13 Less than 1 percentage point variation from the previous year. 
of all nuclear electricity in the world (see Figure 2, left side). In 2002, China held position 15, in 2007 it was tenth, before reaching third place in 2016. Two countries, the U.S. and France, accounted for 47.5 percent of global nuclear production in 2017.

Seven countries' nuclear power generation peaked in the 1990s, among them Belgium, Canada, Japan, and the U.K. A further eleven countries' nuclear generation peaked between 2001 and 2010 including France, Germany, Spain, and Sweden. Fourteen countries generated their maximum amount of nuclear power in the past seven years, five of which peaked in 2017.

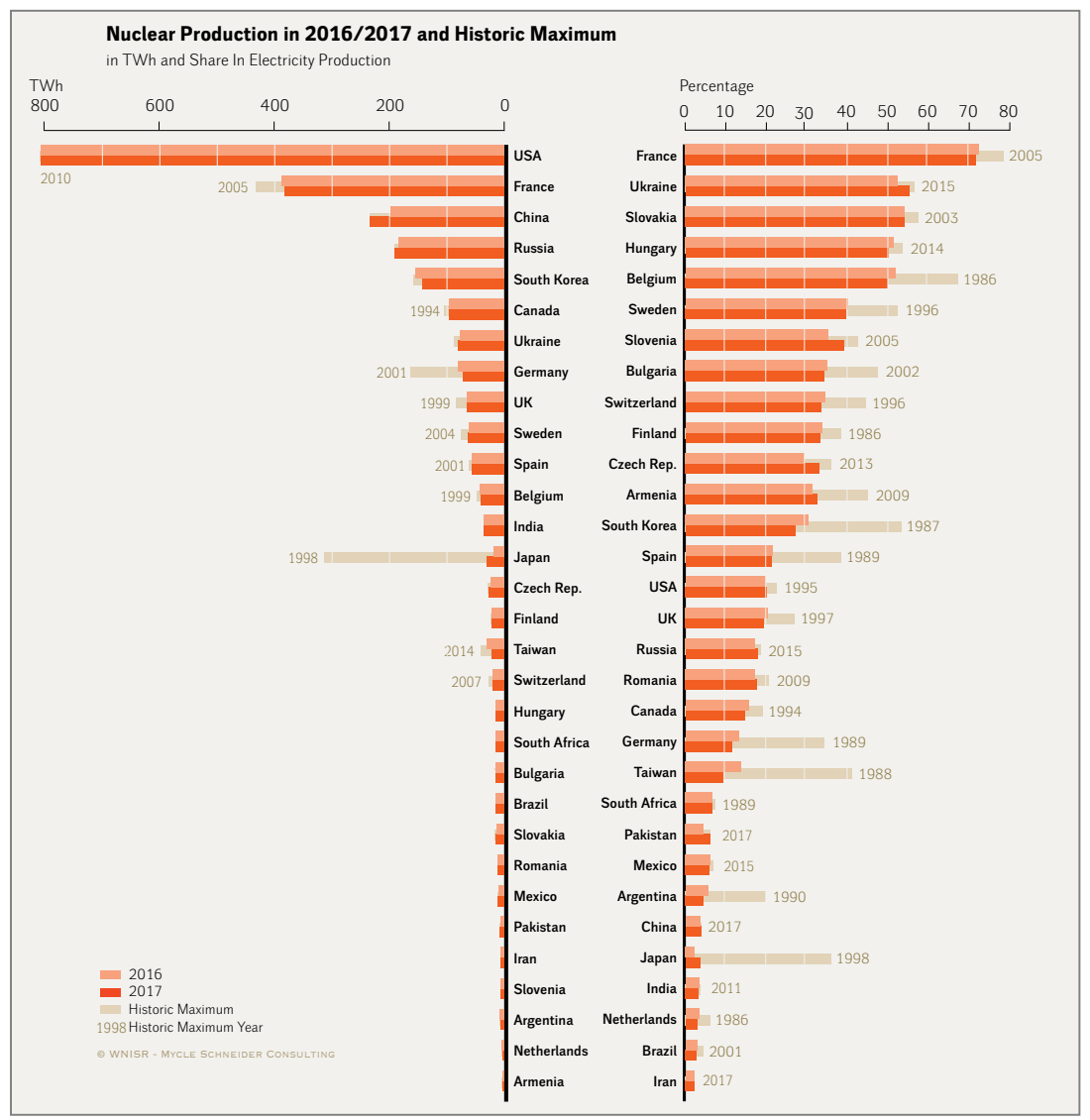

Fig. 2 Nuclear Electricity Generation and Share in Global Power Generation Sources: WNISR, with IAEA-PRIS, 2018, p. 29 
In many cases, even where nuclear power generation augmented, the development is not keeping pace with overall increases in electricity production, leading to a nuclear share below the respective historic maximum (see Figure 2, right side). It is therefore remarkable that in 2017, there were 19 countries that maintained their nuclear share at a constant level (change of less than 1 percentage-point), six countries increased and six decreased the relative share of their nuclear portion.

There were three exceptions in 2017, where countries peaked their respective nuclear share in power generation:

- Starting up three new reactors throughout the year, augmenting production by 18 percent, China increased the 2016 maximum of 3.6 percent, to reach a new record 3.9 percent nuclear share.

- Iran's only commercial reactor started up in 2011 after 33 years of construction but it took another five years to reach a reasonable grid-connection time and load factor in 2016. Increasing production by 7.6 percent, the nuclear share increased again slightly from 2.1 percent to 2.2 percent in 2017 .

- Pakistan has been increasing production of existing units and started up a new one, which led the nuclear to jump from 4.4 percent to 6.2 percent.

\section{Operation, power generation, age distribution}

Since the first nuclear power reactor was connected to the Soviet power grid at Obninsk on 27 June 1954, there have been two major waves of startups. The first peaked in 1974, with 26 grid connections in that year. The second reached a historic maximum in 1984 and 1985, just before the Chernobyl accident, reaching 33 grid connections in each year. By the end of the 1980s, the uninterrupted net increase of operating units had ceased, and in 1990 for the first time the number of reactor shutdowns outweighed the number of startups. The 1991-2000 decade showed far more startups than shutdowns (52/30), while in the decade 2001-2010, startups did not match shutdowns (32/35). Furthermore, after 2000, it took a whole decade to connect as many units as in a single year in the middle of the 1980s. Between 2011 and mid-2018, the startup of 48 reactors - of which 29 (60 percent) in China alone-outpaced by six the closure of 42 units over the same period (see Figure 3).

After the startup of 10 reactors in the world in each of the years 2015 and 2016, only four units started up in 2017, of which three in China and one in Pakistan. 
Three reactors were closed in 2017, respectively the oldest unit in Germany (Gundremmingen-B, 33.5 years), South Korea (Kori-1, 40 years) and Sweden (Oskarshamn-1, 46 years). ${ }^{14}$

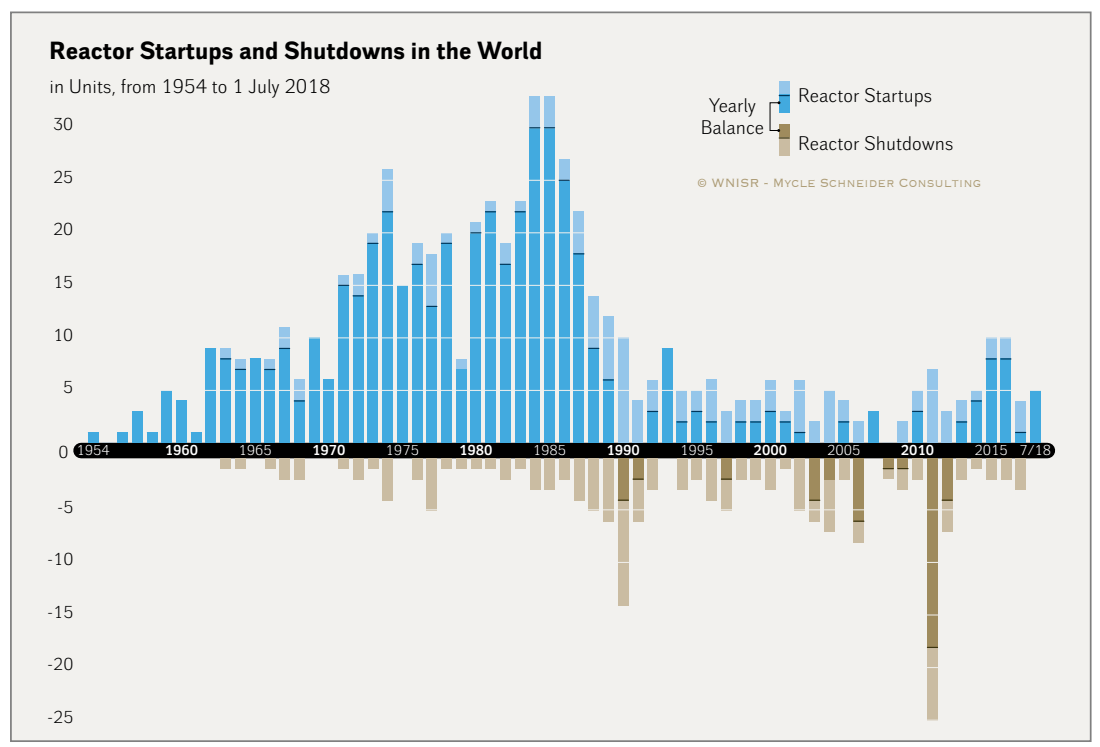

Fig. 3 Nuclear Power Reactor Grid Connections and Shutdowns Sources: WNISR, with IAEA-PRIS, 2018, p. 30

In the first half of 2018, five reactors started up in the world, more than in the entire year of 2017, while none has been closed. Three units were connected to the grid in China, including the first EPR (Taishan-1) and the first AP1000 (Sanmen-1) to start up in the world (see Figure 4). And two reactors started up in Russia, Leningrad 2-1, and Rostov- 4 that began construction 35 years ago. ${ }^{15}$

14 WNISR considers shutdowns from the moment of grid disconnection-and not from the moment of the industrial, political or economic decision-and as the units have not generated power for several years, in WNISR statistics, they are closed in the year of the latest power generation.

15 see https://www.worldnuclearreport.org/35-Years-After-Construction-Start-Rostov-4Reactor-Connected-to-Russian.html. 


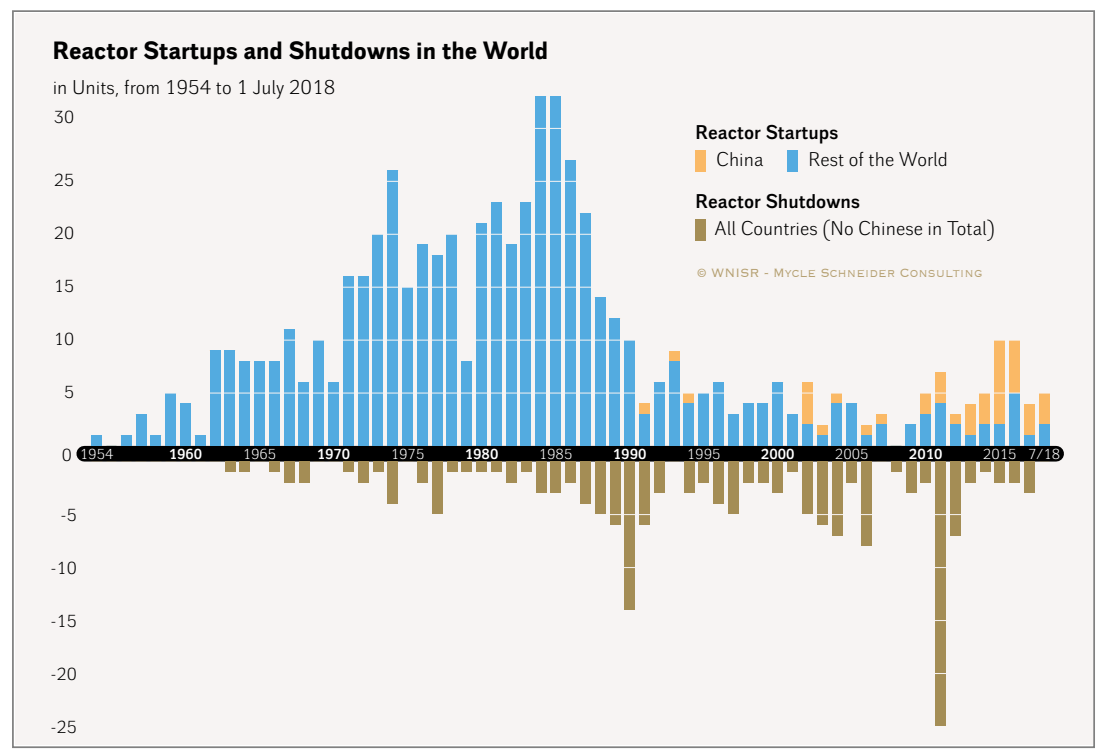

Fig. 4 Nuclear Power Reactor Grid Connections and Shutdowns - The China Effect Sources: WNISR, with IAEA-PRIS, 2018, p. 31

The IAEA continues to count 42 units in Japan in its total number of 453 reactors "in operation" in the world ${ }^{16}$; yet no nuclear electricity was generated in Japan between September 2013 and August 2015, and as of 1 July 2018, only nine reactors were operating. Nuclear plants provided only 3.6 percent of the electricity in Japan in 2017.

The WNISR keeps calling for an appropriate reflection in world nuclear statistics of the unique situation in Japan. The attitude taken by the IAEA, the Japanese government, utilities, industry and many research bodies as well as other governments and organizations to continue considering the entire stranded reactor fleet in the country as "in operation" or "operational" remains a misleading distortion of facts. Steve Kidd, long-time industry strategist, agreed in a WNISR2016 review in Nuclear Engineering International:

16 IAEA, “Power Reactor Information System”, see https://www.iaea.org/pris/ CountryStatistics/CountryDetails.aspx?current=JP, accessed 28 July 2018. 
Including reactors as "operable" along with those definitely in service, when they have not generated power for many years (and don't even have a licence to do so) is clearly ridiculous. ${ }^{17}$

Maybe as a result of such criticism, the World Nuclear Association (WNA), in its second "World Nuclear Performance Report", has distinguished between "generating" and "not generating" nuclear generating capacity. ${ }^{18}$. The IAEA actually does have a reactor-status category called "Long-term Shutdown" or LTS. ${ }^{19}$ Under the IAEA's definition, a reactor is considered in LTS, if it has been shut down for an "extended period (usually more than one year)", and in early period of shutdown either restart is not being "aggressively pursued" or "no firm restart date or recovery schedule has been established". The IAEA lists zero reactors in Japan in the LTS category.

The IAEA criteria are vague and hence subject to arbitrary interpretation. What exactly are extended periods? What is aggressively pursuing? What is a firm restart date or recovery schedule? Faced with this dilemma, the WNISR team in 2014 decided to create a new category with a simple definition, based on empirical fact, without room for speculation: "Long-term Outage" or LTO. Its definition:

A nuclear reactor is considered in Long-term Outage or LTO if it has not generated any electricity in the previous calendar year and in the first half of the current calendar year. It is withdrawn from operational status retroactively from the day it has been disconnected from the grid.

When subsequently the decision is taken to permanently close a reactor, the shutdown status starts with the day of the last electricity generation, and the WNISR statistics are modified retroactively accordingly.

Applying this definition to the world nuclear reactor fleet, as of 1 July 2018, leads to considering 26 Japanese units in LTO. Over the past year, four additional reactors were restarted and three more were officially closed. WNISR considers all ten Fukushima reactors shut down permanently-while the operator Tokyo Electric

17 NEI, "Nuclear power in the world - pessimism or optimism?", 13 October 2016, see http:// www.neimagazine.com/opinion/opinionnuclear-power-in-the-world-pessimism-or-optimism-5031270/, /, accessed 13 August 2017.

18 The World Nuclear Performance Report was launched by WNA in 2016, "perhaps as a reaction to the success of successive WNISRs". In fact, in its September 2015 "Update for Members", WNA reported that its Fuel Report Working Group "discussed the merits of producing an annual nuclear capacity scenario update. Such an update would be a useful communications tool and a counter to the industry-critical World Nuclear Industry Status Report".

19 See IAEA Glossary, at www.iaea.org/pris/Glossary.aspx, accessed 1 July 2016. 
Power Company (TEPCO) has written off the six Daiichi units, it keeps the four Daini reactors in the list of operational facilities. However, it is expected that the Daini plant will shortly be officially released for decommissioning.

As of 1 July 2018, besides the 26 Japanese reactors, two reactors in India (Kakrapar-1 and -2), and one each in China (CEFR), France (Paluel-2) ${ }^{20}$ and Taiwan (Chinshan-1) met the LTO criterion. Besides the restarts in Japan, one reactor each in France (Bugey-5) and Switzerland (Beznau-1), that were categorized as being in LTO status in WNISR2017, were reconnected to the grid, and thus moved back to operational status. The total number of nuclear reactors in LTO as of 1 July 2018 is therefore 32 ; yet all are considered by the IAEA as "in operation".

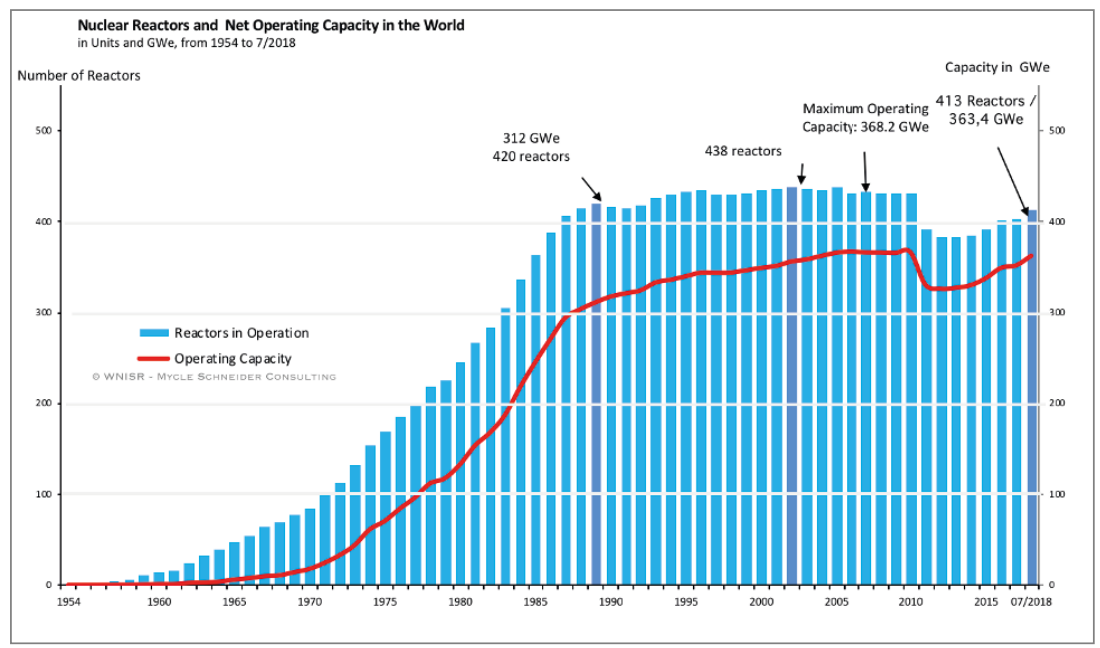

Fig. 5 World Nuclear Reactor Fleet, 1954-2018

Sources: WNISR, with IAEA-PRIS, 2018, p. 33

As of 1 July 2018, a total of 413 nuclear reactors are operating in the world. The current fleet has a total nominal electric net capacity of 363.4 gigawatts (GW or thousand megawatts), see Figure 5.

For many years, the net installed capacity has continued to increase more than the net increase of numbers of operating reactors. This is a result of the combined

20 After many delays, Paluel-2 was reconnected to the grid on 23 July 2018. 
effects of larger units replacing smaller ones and, mainly, technical alterations at existing plants, a process known as uprating. ${ }^{21}$ In the United States alone, the Nuclear Regulatory Commission (NRC) has approved 164 uprates since 1977. The cumulative approved uprates in the United States total 7.9 GW, the equivalent of eight large reactors. ${ }^{22}$

A similar trend of uprates and major overhauls in view of lifetime extensions of existing reactors has been seen in Europe. The main incentive for lifetime extensions is economic but this argument is being increasingly challenged as alternatives become cheaper.

\section{Overview of current new-build}

As of 1 July 2018, 50 reactors are considered here as under construction, the lowest number in a decade, three fewer than a year earlier, and 18 less than in 2013 (five of these projects have already been abandoned since). Four in five reactors are built in Asia and Eastern Europe, and China alone has nearly a third of all reactors under construction (16 out of 50). In total, 15 countries are building nuclear plants (see Table 1).

Five building projects were launched in 2017, two of which in India, and one each in Bangladesh, China (a non-commercial, demonstration fast breeder) and South Korea. As of 1 July 2018, there were two construction starts in the world so far in 2018, one in Russia, (Kursk-2-1) and Turkey (by a Russian company). Just prior to the official construction start in Turkey, the Turkish investors pulled out. It is remarkable that China has not launched a single new construction site for a commercial nuclear plant since December 2016.

Fifty is a relatively small number compared to a peak of 234 units listed as under construction-totalling more than $200 \mathrm{GW}$-in 1979. However, many of those projects (48) were never finished (see Figure 6). The year 2005, with 26 units under construction, marked a record low since the early nuclear age in the 1950s.

21 Increasing the capacity of nuclear reactors by equipment upgrades e.g. more powerful steam generators or turbines.

22 U.S. Nuclear Regulatory Commission (NRC), "Approved Applications for Power Uprates”, Updated 4 May 2018, see http://www.nrc.gov/reactors/operating/licensing/ power-uprates/status-power-apps/approved-applications.html, accessed 28 July 2018. 


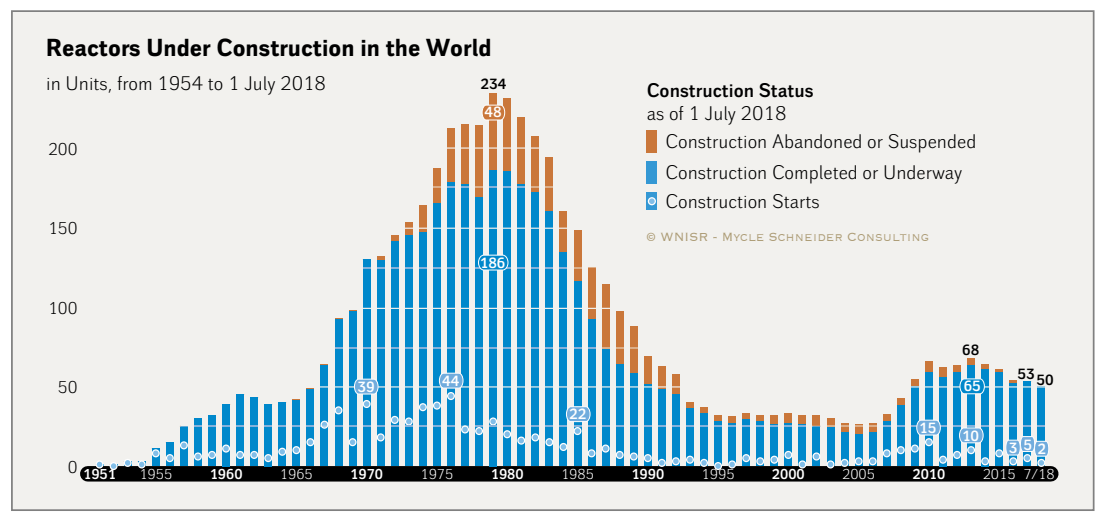

Fig. 6 Nuclear Reactors Under Construction Sources: WNISR, with IAEA-PRIS, 2018, p. 34

Tab. 1 Nuclear Reactors "Under Construction" (as of 1 July 2018)

\begin{tabular}{lrrrcc}
\hline Country & Units & $\begin{array}{c}\text { Capacity } \\
\text { MW net }\end{array}$ & Construction Starts & Grid Connection & $\begin{array}{c}\text { Behind } \\
\text { Schedule }\end{array}$ \\
\hline China & 16 & 15450 & $2009-2017$ & $2018-2023$ & $8-9 ?$ \\
\hline India & 7 & 4824 & $2004-2017$ & $2018-2023$ & 5 \\
\hline Russia & 5 & 3378 & $2007-2018$ & $2019-2022$ & 4 \\
\hline South Korea & 4 & 5360 & $2009-2017$ & $2018-2022$ & 4 \\
\hline UAE & 4 & 5380 & $2012-2015$ & $2020-2021 ?$ & $3-4 ?$ \\
\hline Belarus & 2 & 2218 & $2013-2014$ & $2019-2020$ & $1-2 ?$ \\
\hline Pakistan & 2 & 2028 & $2015-2016$ & $2020-2021$ & - \\
\hline Slovakia & 2 & 880 & $1985-1985$ & $2018-2019$ & 2 \\
\hline USA & 2 & 2234 & $2013-2013$ & $2021-2022$ & 2 \\
\hline Argentina & 1 & 25 & $2014-2014$ & 2020 & 1 \\
\hline Bangladesh & 1 & 1080 & $2017-2017$ & 2023 & - \\
\hline Finland & 1 & 1600 & $2005-2005$ & 2019 & 1 \\
\hline France & 1 & 1600 & $2007-2007$ & 2020 & 1 \\
\hline Japan & 1 & 1325 & $2007-2007$ & $?$ & 1 \\
\hline Turkey & 1 & 1114 & $2018-2018$ & 2023 & - \\
\hline World & 50 & 48496 & $1985-2018$ & $2018-2023$ & $33-36$ \\
\hline
\end{tabular}

Note: This table does not contain suspended or abandoned constructions.

Sources: Compiled by WNISR, 2018, p. 35 


\section{$5 \quad$ Construction times}

\section{Construction times of reactors currently under construction}

A closer look at projects listed as "under construction" illustrates the level of uncertainty and problems associated with many of these projects, especially given that most constructors initially assume a five-year construction period:

- As of 1 July 2018, the 50 reactors being built have been under construction for an average of 6.5 years, many still far from completion.

- All reactors under construction in at least seven (possibly nine) out of a total of 15 countries have experienced mostly year-long delays. At least two thirds (33-36) of all building projects are delayed. Most of the remaining units under construction in the world, were begun within the past three years or have not yet reached projected startup dates, making it difficult to assess, whether or not they are on schedule.

- Of 33 reactors behind schedule, at least 14 have reported increased delays over the past year since WNISR2017.

- At the beginning of the year, 16 reactors were scheduled for startup in 2017, only four made it. Four reactors were scheduled to start up in the second half of 2017, only one did do so, the other three were connected to the grid in the first half of 2018.

- As of mid-2017, a total of 19 reactors were scheduled for startup in 2018. As of mid-2018, only three of these reactors were connected to the grid (one of which was already connected in 2017) and seven have been officially delayed until at least 2019.

- Two projects have been listed as "under construction" for more than 30 years, Mochovce-3 and - 4 in Slovakia. Rostov- 4 in Russia was finally connected to the grid in February 2018, 35 years after construction start.

- Four reactors have been listed as "under construction" for a decade or more, the Prototype Fast Breeder Reactor (PFBR) in India, the Olkiluoto-3 reactor project in Finland, Shimane-3 in Japan and the French Flamanville-3 unit.

It should be stressed that the actual lead time for nuclear plant projects includes not only the construction itself but also lengthy licensing procedures in most countries, complex financing negotiations, site preparation and other infrastructure development. As the U.K.'s Hinkley Point C illustrates, a significant share of investment and work can be carried out before even entering the official construction phase. 


\section{Construction times of past and currently operating reactors}

There has been a clear global trend towards increasing construction times. National building programs were faster in the early years of nuclear power. As Figure 7 illustrates, construction times of reactors completed in the 1970s and 1980s were quite homogenous, while in the past three decades they have varied widely. The four units completed in 2017 by the Chinese nuclear industry in the homeland ( 3 units) and in Pakistan (1 unit) average an excellent 4.9 years construction time. This is only the second time since 2005 that world average construction time dropped below 5 -year average. However, the five units that started up in the first half of 2018 show a much lower performance with an average of 13.4 years construction.

The longer-term perspective illustrates that short construction times remain the exceptions. Nine countries completed 55 reactors over the past decade after an average construction time of just over ten years (see Table 2). While the average has hardly moved since 2014, the range increased from 3.8-36.3 years to $4.1-43.5$ years (the Watts Bar-2 in the U.S. record, which will remain the upper limit for some time to come).

Tab. 2 Reactor Construction Times 2008-2018

\begin{tabular}{lcccc}
\hline & Construction Times of 55 Units Started-up 2008-7/2018 \\
\cline { 3 - 4 } Country & Units & \multicolumn{3}{c}{ Construction Time (in Years) } \\
\cline { 3 - 4 } & & Mean Time & Minimum & Maximum \\
\hline China & 31 & 6 & 4.1 & 11.2 \\
\hline Russia & 7 & 24.0 & 8.1 & 35.1 \\
\hline India & 5 & 9.8 & 7.2 & 14.2 \\
\hline South Korea & 5 & 5.3 & 4.1 & 7.2 \\
\hline Pakistan & 3 & 5.4 & 5.2 & \\
\hline Argentina & 1 & 33.0 & & \\
\hline Iran & 1 & 36.3 & & \\
\hline Japan & 1 & 5.1 & & 43.5 \\
\hline USA & 1 & 43.5 & & \\
\hline World & 55 & 10.1 & & \\
\hline
\end{tabular}

Sources: WNISR, with IAEA-PRIS, 2018, p. 37 


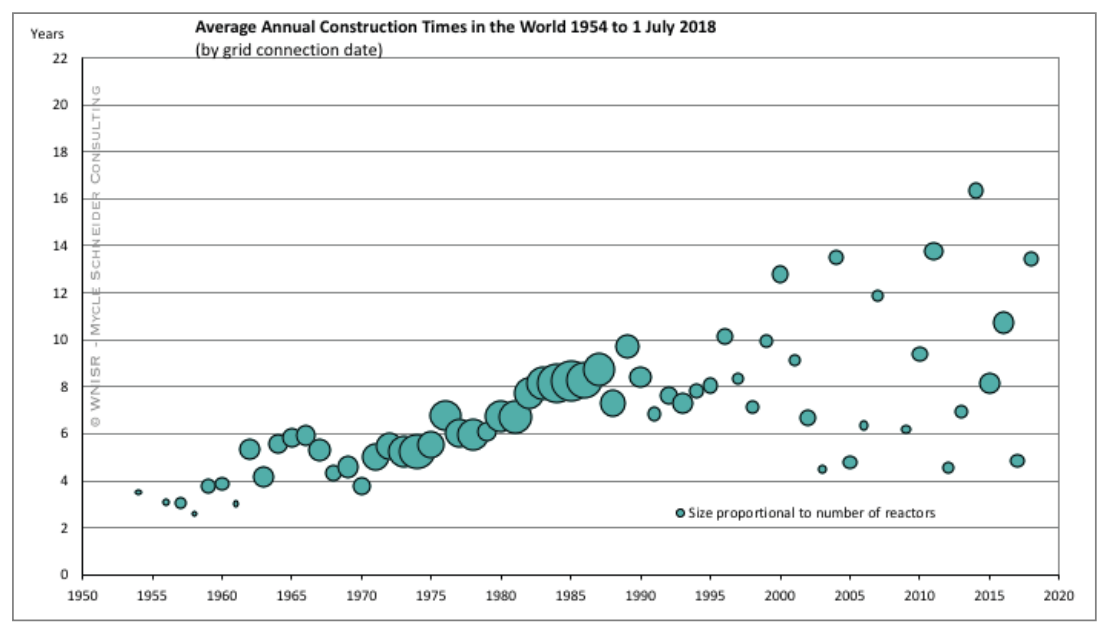

Fig. 7 Average Annual Construction Times in the World Sources: WNISR, with IAEA-PRIS, 2018, p. 37

\section{Construction starts and cancellations}

The number of annual construction-starts ${ }^{23}$ in the world peaked in 1976 at 44, of which 12 projects were later abandoned. In 2010, there were 15 construction starts-including 10 in China alone-the highest level since 1985 (see Figure 8). That number dropped to 10 in 2013, eight in 2015, five in 2017 and two in 2018 as of mid-year.

Seriously affected by the Fukushima events, China did not start any new building site in 2011 and 2014. While Chinese utilities began constructing six more units in 2015, the number shrank to two in 2016, only a demonstration fast reactor in 2017 and none in 2018 as of mid-year (see Figure 9). In other words, since December 2016, China has not started building a new commercial reactor.

23 Generally, a reactor is considered under construction, when the base slab of the reactor building is being concreted. Site preparation work, excavation and other infrastructure developments are not included. 


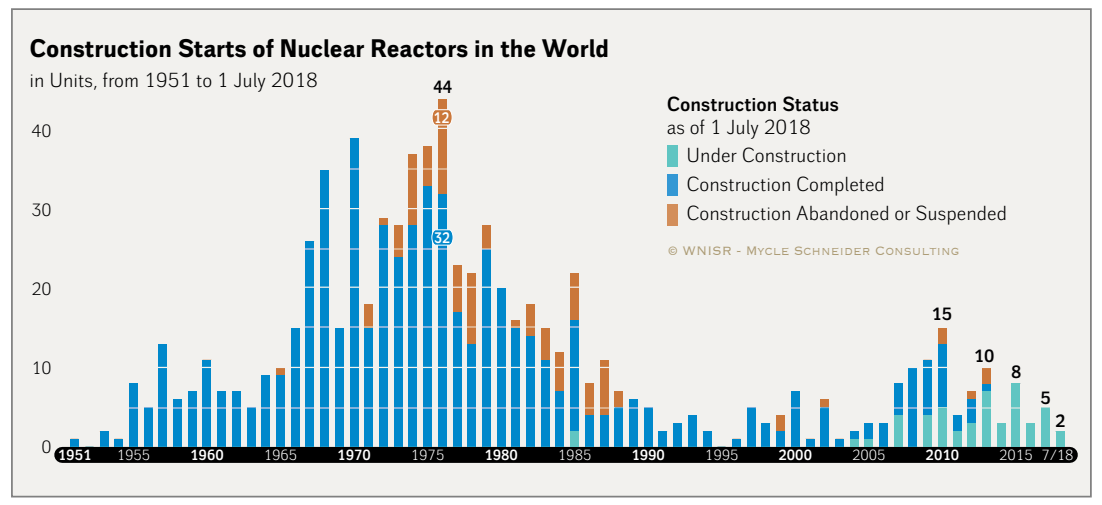

Fig. 8 Construction Starts in the World

Sources: WNISR, with IAEA-PRIS, 2018, p. 38

Over the decade 2008-2017, construction began on 76 reactors in the world (of which five have been later cancelled), that is twice the rate of the decade 1998-2007, when work started on 38 units (of which three have been abandoned). However, close to half (51) of these 114 building starts over the past two decades were in China alone (see Figure 9).

In addition, past experience shows that simply having an order for a reactor, or even having a nuclear plant at an advanced stage of construction, is no guarantee of ultimate grid connection and power production. The abandonment of the two V.C. Summer units at the end of July 2017 after four years of construction and a multi-billion-dollar investment is only the latest example in a long list of failed nuclear power plant projects.

French Atomic Energy Commission (CEA) statistics through 2002 indicate 253 "cancelled orders" in 31 countries, many of them at an advanced construction stage (see also Figure 10). The United States alone accounted for 138 of these order cancellations. ${ }^{24}$

24 French Atomic Energy Commission (CEA), "Elecnuc-Nuclear Power Plants in the World", 2002. The section "cancelled orders" has disappeared after the 2002 edition. 


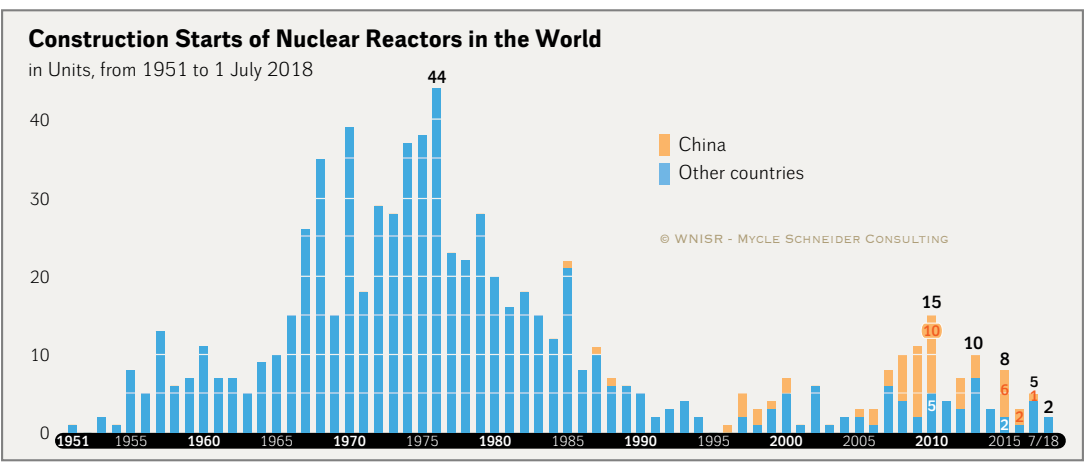

Fig. 9 Construction Starts in the World/China Sources: WNISR, with IAEA-PRIS, 2018, p. 39

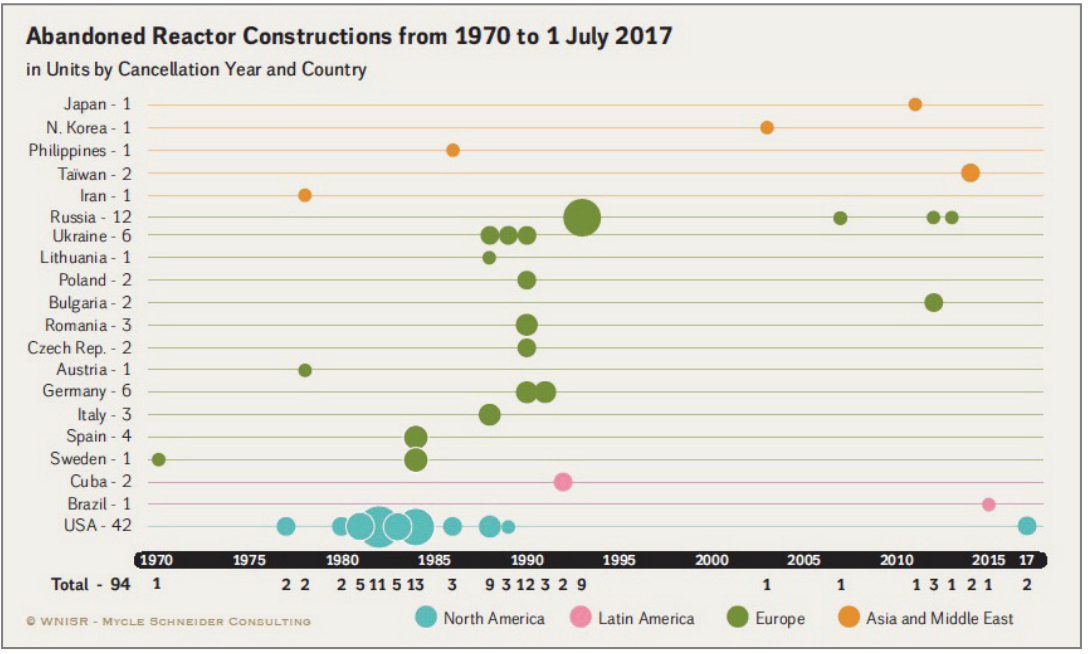

Fig. 10 Cancelled or Suspended Reactor Constructions (Note: This graph only includes constructions that had already officially started).

Sources: WNISR, with IAEA-PRIS, 2018, p. 39 
Of the 762 reactor constructions launched since 1951, at least 94 units (12 percent) in 20 countries had been abandoned as of 1 July 2018. The past decade shows about half of the historic abandoning rate of one in eight constructions, as five in 76 building sites officially started during that period were later given up at various stages of advancement.

Close to three quarters (66 units) of all cancelled projects were in four countries alone-the U.S. (42), Russia (12), Germany and Ukraine (six each). Some units were actually 100 percent completed-including Kalkar in Germany and Zwentendorf in Austria-before the decision was taken not to operate them.

There is no thorough analysis of the cumulated economic loss of these failed investments.

\section{$7 \quad$ Operating age}

In the absence of any significant new-build and grid connection over many years, the average age (from grid connection) of operating nuclear power plants has been increasing steadily and at mid-2017 stands at 29.9 years (see Figure 11). ${ }^{25} \mathrm{~A}$ total of 254 reactors (61.5 percent) have operated for 31 and more years, including 77 (18.5 percent) reaching 41 years and more.

Some nuclear utilities envisage average reactor lifetimes of beyond 40 years up to 60 and even 80 years. In the United States, reactors are initially licensed to operate for 40 years, but nuclear operators can request a license renewal for an additional 20 years from the Nuclear Regulatory Commission (NRC). As of 4 May 2018, 87 of the 99 operating U.S. units have received an extension, with another four applications for five reactors under NRC review. ${ }^{26}$

25 WNISR calculates reactor age from grid connection to final disconnection from the grid and "startup" is synonymous with grid connection and "shutdown" with withdrawal from the grid..

26 NRC, "Status of License Renewal Applications and Industry Activities", Updated 4 May 2018, see http://www.nrc.gov/reactors/operating/licensing/renewal/applications. html, accessed 29 July 2018. 


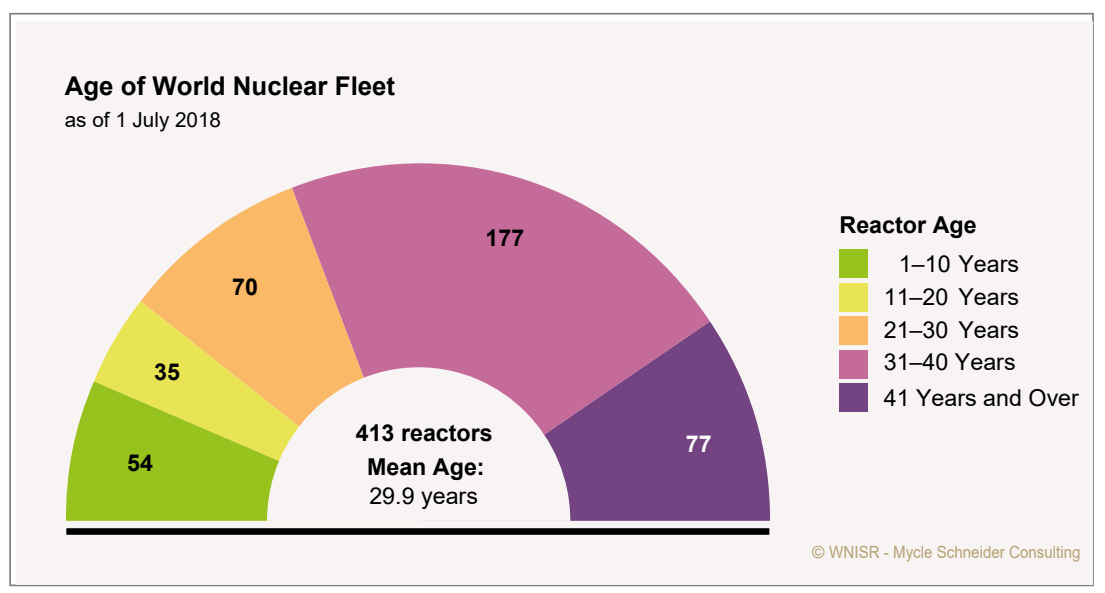

Fig. 11 Age Distribution of Operating Reactors in the World Sources: WNISR, with IAEA-PRIS, 2018, p. 41

In the U.S., only two of the 34 units that have been shut down had reached 40 years on the grid-Vermont Yankee, closed in December 2014, at the age of 42, and Fort Calhoun, shut down in October 2016, after 43 years of operation. Both had obtained licenses to operate up to 60 years but were closed only two and three years into lifetime extension respectively, mainly for economic reasons. In other words, at least a quarter of the reactors connected to the grid in the U.S. never reached their initial design lifetime of 40 years. On the other hand, of the 99 currently operating plants, 44 units have operated for 41 years and more; thus, half of the units with license renewals have already entered the life extension period, and that share is growing rapidly with the mid-2018 average age of the U.S. operational fleet at 38.1 years.

Many other countries have no specific time limits on operating licenses. In France, where the country's first operating Pressurized Water Reactor (PWR) started up in 1977, reactors must undergo in-depth inspection and testing every decade against reinforced safety requirements. The French reactors have operated for 33.4 years on average, and the oldest have completed the process with the French Nuclear Safety Authority (ASN) evaluating each reactor before allowing a unit to operate for more than 30 years. They could then operate until they reach 40 years, which is the limit of their initial design age. However, the assessments are years behind schedule. The French utility Électricité de France (EDF) clearly prioritizes lifetime extension to 50 years over large-scale new-build. In a recent presentation, EDF states: "Continuing operation beyond 40 years means allowing for the progressive increase 
of renewable energies while guaranteeing a lasting, quasi entirely decarbonized and continuous electricity supply thanks to the flexibility of the nuclear fleet."27

EDF's general approach to lifetime extension is currently under review by ASN's Technical Support Organization, the Institute for Radiation Protection and $\mathrm{Nu}-$ clear Safety (IRSN) and is now scheduled to be examined by its expert committees (Groupes Permanents) in 2018 and 2019. ASN plans to provide its opinion on the general assessment outline by 2020. In addition, lifetime extension beyond 40 years requires site-specific, time-consuming public enquiries.

Current French energy legislation requires planning to limit the nuclear share in power production to 50 percent by 2025 . The implementation of this legislationeven if the 2025 target was to be delayed as is currently discussed-in a context of stagnating electricity consumption, would mean the closure of about one third of the French reactor fleet. In other words, many of the lifetime extensions would become obsolete. No point in investing large amounts of money into upgrading if the plant is shut down shortly after. A particularly difficult aspect of the lifetime management in France is that the units licensed to use plutonium-uranium mixed oxide fuel (MOX) are also amongst the oldest reactors. The criteria for selection of reactors to be closed remain under discussion.

In assessing the likelihood of reactors being able to operate for 50 or 60 years, it is useful to compare the age distribution of reactors that are currently operating with those that have already shut down (see Figure 11 and Figure 12). As of mid-2018, 77 of the world's reactors have operated for 41 years and more, and a total of 81 that have already passed their 40 -year lifetime are considered in lifetime extension. ${ }^{28}$ As the age pyramid illustrates, that number could rapidly increase over the next few years. A total of 254 units have already reached or exceeded age 31 .

The age structure of the 173 units already shut down completes the picture. In total, 60 of these units operated for 31 years and more, and of those, 20 reactors operated for 41 years and more (see Figure 12). Many units of the first-generation designs only operated for a few years. Considering that the average age of the 173 units that have already shut down is about 25 years, plans to extend the operational lifetime of large numbers of units to 40 years and far beyond seemed rather optimistic. However, the operating time prior to shutdown has clearly increased continuously. But while the average annual age at shutdown got close to 40 years, it only passed that age in two years so far: in 2014, when the only such unit shut

27 EDF, "Le parc nucléaire en exploitation en France : Exploitation, maintenance et Grand Carénage", 11 January 2018.

28 WNISR considers the age starting with grid connection, and while figures used to be rounded by half-years, as of WNISR2016 they are rounded by the tenth of the year. 
down that year (Vermont Yankee in the U.S.) after 42 years of operation; and in 2016, with two reactors shutting down at age 43 (Fort Calhoun, U.S.) and 45 (Novovoronezh, Russia) respectively.

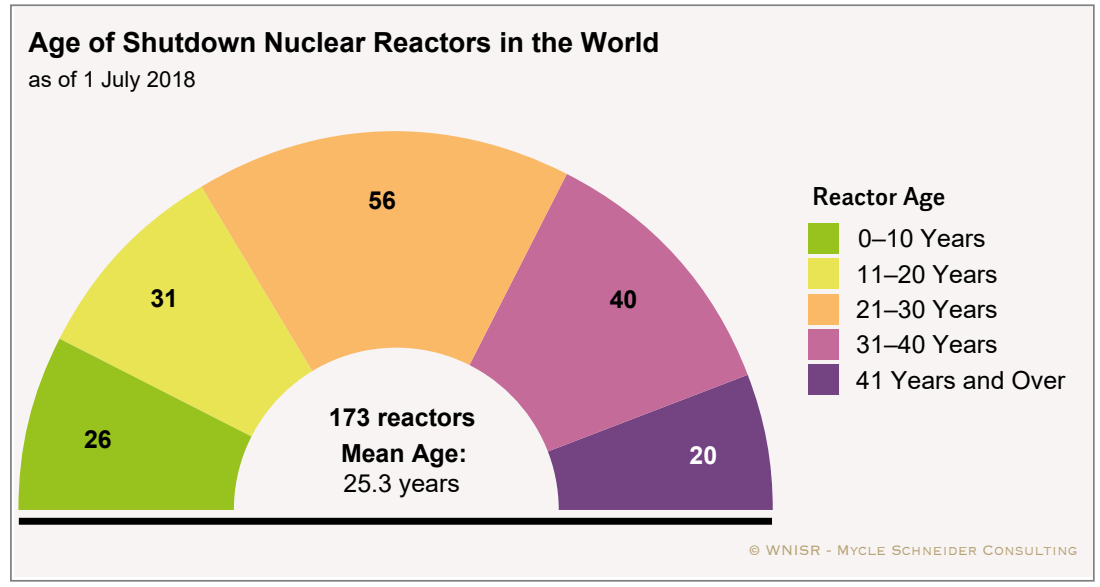

Fig. 12 Age Distribution of Shut Down Nuclear Power Reactors Sources: WNISR, with IAEA-PRIS, 2018, p. 43

As a result of the Fukushima nuclear disaster, more pressing questions have been raised about the wisdom of operating older reactors. The Fukushima Daiichi units ( 1 to 4 ) were connected to the grid between 1971 and 1974. The license for unit 1 had been extended for another 10 years in February 2011, one month before the catastrophe began. Four days after the initial events in Japan began, the German government ordered the shutdown of seven reactors that had started up before 1981 (plus one commissioned in 1983). The sole, decisive selection criterion was operational age. Other countries did not adopt the same approach, but it is clear that the 3/11 events had an impact on previously assumed extended lifetimes in other countries as well, including in Belgium, Switzerland, and Taiwan. And more recently, in the first half of 2017, South Korea's incoming President Moon shut down the country's oldest reactor (Kori-1), explicitly at the age of forty, ruling out lifetime extensions in the future. Sweden also closed its oldest unit, Oskarshamn-1 at age 46. And Germany shut down its then oldest reactor, Gundremmingen- $B$, at yearend 2017, at age 33. The average age of these three units remains with 39.9 years again just below 40 . 


\section{$8 \quad$ Potential newcomer countries}

The International Atomic Energy Agency (IAEA) assumes that to meet their prediction of more than doubling of current capacity in the higher nuclear scenario, considerable new construction will occur in existing nuclear countries, such as China, South Korea and India, but also envisages significant capacity build-up in newcomer countries.

The industry's lobby organisation WNA suggests that there are 20 countries in which nuclear power is being planned for the first time, with an additional 20 , where the nuclear option is under consideration. Notwithstanding any reality check of these assumptions, this is small compared to renewable energy, as at end of 2015, targets had been established in 173 countries at the national or state/provincial level. ${ }^{29}$ The WNA further categorizes those countries in which nuclear power is being planned into five separate groups ${ }^{30}$ :

- Power reactors under construction: United Arab Emirates (UAE), Belarus.

- Contracts signed, legal and regulatory infrastructure well-developed or developing: Lithuania, Turkey, Bangladesh, Vietnam (but deferred).

- Committed plans, legal and regulatory infrastructure developing: Jordan, Poland, Egypt.

- Well-developed plans but commitment pending: Thailand, Indonesia, Kazakhstan, Saudi Arabia, Chile; or commitment stalled: Italy.

- Developing plans: Israel, Nigeria, Kenya, Laos, Malaysia, Morocco, Algeria.

The following section will look at the countries, in which WNA considers nuclear power plants are at least 'committed plans'.

\section{Under construction}

\section{Bangladesh}

On 30 November 2017, Bangladesh officially began construction of the first unit of the Rooppur nuclear plant. ${ }^{31}$ Unit 1 is now scheduled to begin operation in 2023

29 REN21, "Renewables 2016-Global Status Report”, Renewable Energy Policy Network for the 21st Century, 2016.

30 WNA, “Emerging Nuclear Energy Countries”, January 2018, see http://www.world-nuclear. org/information-library/country-profiles/others/emerging-nuclear-energy-countries. aspx.

31 WNISR, “Construction Start at First Nuclear Power Plant in Bangladesh", 5 April 2018, see https://www.worldnuclearreport.org/Construction-Start-at-First-Nuclear-Power- 
followed by unit 2 in $2024 .^{32}$ The idea of building nuclear reactors at Rooppur goes back to even before Bangladesh became an independent country, to a 1963 plan by the Pakistan Atomic Energy Commission to build one reactor in West Pakistan and one in East Pakistan. ${ }^{33}$

The current reactor deal dates back to November 2011 when the Bangladeshi Government announced that it was prepared to sign a deal with the Russian Government for two $1000 \mathrm{MW}$ units-the first of which was to start up between 2017 and 2018-at a total cost of US\$1.5-2 billion. ${ }^{34}$ Since then, although negotiations have reportedly been ongoing, the startup date has been continually postponed and the expected construction cost has risen sharply.

By 2015, the Bangladeshi Finance Minister was quoted as saying the project was then expected to cost US\$12.65 billion. ${ }^{35}$ A December 2015 agreement was said to be signed between the Bangladesh Atomic Energy Commission and Rosatom for $2.4 \mathrm{GW}$ of capacity, with work then expected to begin in 2016 and operation to start in 2022 and $2023 .{ }^{36}$ According to the deal, Russia would provide 90 percent of the funds on credit at an interest rate of Libor plus 1.75 percent. In late May 2016, negotiations were concluded over the US $\$ 12.65$ billion project, with Russia making available US $\$ 11.385$ billion. ${ }^{37}$ In April 2017, Tass, the Russian news agency, reported that permission to start construction had been granted and that work would commence in the second half of $2017 . .^{38}$

Plant-in-Bangladesh.html, accessed 29 June 2018.

32 NEI, "Work begins on foundation for unit 1 of Bangladesh NPP", see http://www. neimagazine.com/news/newswork-begins-on-foundation-for-unit-1-of-bangladeshnpp-6107152/, accessed 22 April 2018.

33 IAEA, "Bangladesh", Country Nuclear Power Profiles, 2012, see https://www-pub.iaea. org/mtcd/publications/pdf/cnpp2012_cd/countryprofiles/Bangladesh/Figures/Bangladesh\%20CNPP.pdf, accessed 8 May 2018.

34 Srinivas Laxman, "Bangladesh \& Russia Sign N-Plant Deal For Two Reactors At Rooppur, Asian Scientist”, Asian Scientist, 4 November 2011, see https://www.asianscientist. com/2011/11/topnews/rooppur-nuclear-power-project-bangladesh-russia-sign-nuclear-agreement-2011/, accessed 22 April 2018.

35 WNN, “Bangladesh, Russia ink \$12.65 billion Rooppur plant deal”, 29 December 2015, see http://www.world-nuclear-news.org/NN-Bangladesh-Russia-ink-12.65-billionRooppur-plant-deal-29121501.html, accessed 22 April 2018.

36 WNN, “Bangladesh, Russia Ink \$12.65 Billion Rooppur Plant Deal” (ref. 4).

37 NEI, "Russia initials credit agreement with Bangladesh for Rooppur NPP”, 30 May 2016, see http://www.neimagazine.com/news/newsrussia-initials-credit-agreement-with-bangladesh-for-rooppur-npp-4907672/, accessed 22 April 2018.

38 TASS, "Rosatom plans to launch construction of Ruppur power plant in Bangladesh", 19 April 2017, see http://tass.com/economy/942156. 
The project's economics have been widely questioned. Earlier in 2017, a retired nuclear engineer who had been involved in advising the Bangladesh Atomic Energy Commission (BAEC), argued in one of the leading English-language newspapers in Bangladesh that the country was "paying a heavy price" for BAEC not having "undertaken a large-scale programme of recruitment, and training of engineers"; he also charged that Bangladesh was buying reactors at the "unreasonable and unacceptable" price of US $\$ 5,500 / \mathrm{kW}$ because its "negotiators didn't have the expertise to properly scrutinise the quoted price". ${ }^{39}$

\section{Belarus}

Construction started in November 2013 at Belarus's first nuclear reactor at the Ostrovets power plant, also called Belarusian-1. Construction of a second $1200 \mathrm{MWe}$ AES-2006 reactor started in June 2014. In November 2011, the Russian and Belarusian governments agreed that Russia would lend up to US $\$ 10$ billion for 25 years to finance 90 percent of the contract between Atomstroyexport and the Belarus Directorate for Nuclear Power Plant Construction. In July 2012, the contract was signed for the construction of the two reactors for an estimated cost of US $\$ 10$ billion. ${ }^{40}$ The project assumes liability for the supply of all fuel and repatriation of spent fuel for the life of the plant. The fuel is to be reprocessed in Russia and the separated wastes returned to Belarus. When construction started, it was stated that the reactors will be completed until 2018 and 2020 respectively. ${ }^{41}$ In August 2016, the reactor pressure vessel of unit one slipped and fell two meters before hitting the ground, during installation. This lead to an eight-month delay, while it was replaced.$^{42}$ In March 2018, the head of the reactor division at the power plant said that it was then expected that electricity would be supplied to the grid in the $4^{\text {th }}$ Quarter of 2019 with the second one online in July $2020{ }^{43}$

39 Abdul Martin, "The economics of the Rooppur Nuclear Power Plant”, The Daily Star, 2 March 2017, see https://www.thedailystar.net/op-ed/economics/the-economics-the-rooppur-nuclear-power-plant-1369345, accessed 22 April 2018.

40 NIW, "Belarus, Aided by Russia and Broke, Europe's Last Dictatorship Proceeds With NPP”, 28 September 2012.

41 WNN, “Ostrovets plant meets construction safety rules”, 7 November 2014, see http://www. world-nuclear-news.org/NN-Ostrovets-plant-meets-construction-safety-rules-07111401. html, accessed 21 April 2018.

42 NIW, “Briefs-Belarus”, 7 April 2017.

43 Belarus News, "Belarusian nuclear power plant to give electricity to national power grid in Q4 2019”, Belarus News, 28 March 2018, see http://eng.belta.by/economics/ view/belarusian-nuclear-power-plant-to-give-electricity-to-national-power-grid-in -q1-2019-110418-2018/. 
The official cost of the project has increased by 26 percent, to 56 billion Russian roubles, in 2001 prices (US\$ ${ }_{2001} 1.8$ billion). ${ }^{44}$ However, the falling exchange rate of the rouble against the dollar significantly affects the dollar price of the project.

The project is the focus of international opposition and criticism, with formal complaints from the Lithuanian government, that has published a list of fundamental problems of the project. ${ }^{45}$ The Belarussian government, in order to allay European concerns about Ostrovets submitted the project to a post-Fukushima nuclear stress test and it produced in 2017 a national report, which is currently submitted to peer-review by a commission from the European nuclear regulators group ENSREG and the European Commission. In July 2018, the European Commission announced that the report had been presented to the Belarussian authorities and the executive summary was made public, which concludes that "although the report is overall positive, it includes important recommendations that necessitate an appropriate follow up" ${ }^{46}$ The next step is these recommendations need to be incorporated into the next draft of the National Action Plan. ${ }^{47}$

Belarus has historically been an importer of electricity from Russia and Ukraine. But in May 2018, Vice-Premier Vladimir Semashko stated: "In 2018 we stopped electric energy import, because we had upgraded our own power grid. We are self-reliant and can provide ourselves with our own electric energy." ${ }^{48}$ In fact, Semashko claims that in the first four months of 2018, Belarus exported 0.4 TWh. The startup of the Ostrovets nuclear plant would significantly increase excess capacity. Lithuania has said it will not accept any electricity from Belarus and is trying to get is neighbours to follow the ban. Currently this has not been successful,

44 Charter 97, “Astravets NPP Becomes 12 Billion More Expensive In One Day”, see https:// charter97.org/en/news/2016/12/30/236059/, accessed 21 April 2018.

45 Bryan Bradley, "Lithuania Urges Belarus to Halt Nuclear Project on Safety Issues", Bloomberg, 20 August 2013, see https://www.bloomberg.com/news/articles/2013-08-20/ lithuania-urges-belarus-to-halt-nuclear-project-on-safety-issues, accessed 22 April 2018.

46 ENSREG, "Belarus Stress Tests Peer Review - Executive summary”, European Nuclear Safety Regulators Group, July 2018, see http://www.ensreg.eu/sites/default/files/attachments/hlg_p2018-36_156_belarus_stress_test_prt_report_-_executive_summary_0. pdf accessed 5 July 2018.

47 European Commission, "Comprehensive risk and safety assessments of the Belarus nuclear power plant completed” (Press Release), 3 July 2018, see http://europa.eu/rapid/ press-release_IP-18-4347_en.htm, accessed 4 July 2018.

48 Belarus News, "Belarus ramps up electricity export in 2018”, 14 May 2018, see http:// eng.belta.by/economics/view/belarus-ramps-up-electricity-export-in-2018-111638-2018/, accessed 3 July 2018. 
although there has been an agreement to introducing an electricity import tax. ${ }^{49}$ Russia is currently upgrading its grid connection between the Leningradskaya and Smolensk nuclear power stations, thus potentially also enabling a better connection of Ostrovets to the West-Russian electricity grid, circumventing the Baltic States. Vice-Premier Semashko is confident: "Our energy is cheaper, and it will be on demand on this market." ${ }^{\text {50 }}$

\section{Turkey}

In Turkey, three separate projects are being developed with three different reactor designs and three different sets of financial sources. Despite this, in early 2018, construction formally began on the first of these projects.

Some four decades after the first ideas came up for a nuclear power plant at Akkuyu, in the province of Mersin on Turkey's Mediterranean coast, construction started in April 2018, a day before President Putin of Russia visited Turkey for the official launch of the project. ${ }^{51}$ The power plant is to be implemented by Rosatom of Russia under a Build-Own-Operate- (BOO) model. In February 2018, only two months prior to the official construction start, Rosatom's Turkish partners pulled out. The consortium of private companies Cengiz Holding, Kolin Insaat Turizm Sanayi ve Ticaret et Kalyon Insaat Sanayi ve Ticaret, which was to hold 49 percent of the shares, quit the project because they expected too little benefits from the project. ${ }^{52}$

A company, JSC Akkuyu Nuclear has been established to ensure construction of the project and has been designated as the Strategic Investor. According to the establishing agreement, at least 51 percent of shares in the finished project should belong to Russian companies and up to 49 percent of shares can be available for sale to outside investors. Negotiations with potential Turkish investors continue

49 Reuters, "Baltics to cooperate on Belarus nuclear power tax", 14 December 2017, see https://www.reuters.com/article/baltics-energy/baltics-to-cooperate-on-belarus-nuclear-power-tax-idUSL8N1OC3QD, accessed 22 April 2018.

50 Belarus News, "Belarus ramps up electricity export in 2018”, op.cit.

51 Tuvan Gumrukeu and Orhan Coskun, "Turkey grants Rosatom construction license for first unit of Akkuyu...”, Reuters, 2 April 2018, see https://www.reuters.com/article/ us-turkey-russia-nuclearpower/turkey-grants-rosatom-construction-license-for-firstunit-of-akkuyu-nuclear-plant-idUSKCN1H91OY, accessed 22 May 2018.

52 AFP, "Un consortium turc se retire du projet de la centrale nucléaire d'Akkuyu", see https://www.romandie.com/news/887776.rom, accessed 4 July 2018. 
after the three prospective partners withdrew. ${ }^{53}$ However, Rosatom has stated that it would be able to complete the project even if it is unable to attract local investors. ${ }^{54}$

An agreement was signed in May 2010 for four VVER1200 reactors (Generation III+), with construction originally expected to start in 2015. At the heart of the project is a 15-year Power Purchase Agreement (PPA), which includes 70 percent of the electricity produced from units 1 and 2 and 30 percent of units 3 and 4 . Therefore 50 percent of the total power from the station is to be sold at a guaranteed price for the first 15 years, with the rest to be sold on the market.

After a fresh series of delays, on 3 March 2017, Akkuyu JSC applied for a construction license. ${ }^{55}$ Rosatom stated: "According to the Intergovernmental Agreement, the commissioning of the first power unit must take place no later than 7 years after the issuance of all permits for construction by the Republic of Turkey." ${ }^{\prime 6}$

In July 2017 the European Parliament adopted a resolution which called on the Turkish Government to halt the plans for the construction of the Akkuyu project due to its location in a region prone to severe earthquakes and called on "the Turkish Government to involve, or at least consult, the governments of its neighbouring countries, such as Greece and Cyprus." ${ }^{.7}$

In April 2018, a construction license was awarded, and the first concrete was poured, with first electricity expected to be in 2023 (the $100^{\text {th }}$ anniversary of the founding of the modern state of Turkey), with all four units to be operational by $2025 .^{58}$ (See "Contract Signed" section hereunder for information on further projects in Turkey.)

53 Rosatom, "JSC Akkuyu Nuclear designated strategic investor in Turkey", 2 April 2018, see http://www.rosatom.ru/en/press-centre/news/jsc-akkuyu-nuclear-designated-strategic-investor-in-turkey/, accessed 20 April 2018.

54 Reuters, "Russia is able to complete Akkuyu nuclear power plant construction: Russian minister", 6 April 2018, see http://www.hurriyetdailynews.com/russia-is-able-to-complete-akkuyu-nuclear-power-plant-construction-russian-minister-129886, accessed 6 April 2018.

55 WNN, "Akkuyu project receives production licence"," see http://www.world-nuclear-news. org/NN-Akkuyu-project-receives-production-licence-16061701.html, accessed 22 April 2018.

56 Coskun, “Turkey's First Nuclear Plant Facing Further Delays - Sources” (ref. 32).

57 European Parliament, "P8_TA(2017)0306, 2016 Report on Turkey European Parliament resolution of 6 July 2017 on the 2016 Commission Report on Turkey (2016/2308(INI))", 6 July 2017, see http://www.europarl.europa.eu/sides/getDoc.do?pubRef=-//EP//NONSGML+TA+P8-TA-2017-0306+0+DOC+PDF+V0//EN, accessed 22 April 2018.

58 NEI, “Construction of Turkey's Akkuyu NPP begins”, 4 April 2018, see http://www. neimagazine.com/news/newsconstruction-of-turkeys-akkuyu-npp-begins-6102914/, accessed 22 April 2018. 


\section{United Arab Emirates}

In the United Arab Emirates (UAE), construction is ongoing at the Barakah nuclear project, $300 \mathrm{~km}$ west of $\mathrm{Abu} \mathrm{Dhabi}$, where there are four reactors under construction. At the time of the contract signing in December 2009 with Korean Electric Power Corp., the Emirates Nuclear Energy Corp (ENEC), said that "the contract for the construction, commissioning and fuel loads for four units equalled approximately US $\$ 20$ billion, with a high percentage of the contract being offered under a fixed-price arrangement". ${ }^{59}$

The total cost of the project is at least $€ 24.4$ billion (US $\$ 28.2$ billion). The financing for this was US $\$ 16.2$ billion Abu Dhabi's Department of Finance, equity financing US $\$ 4.7$ billion, US $\$ 2.5$ billion through a loan from the Export-Import Bank of Korea, with loan agreements from the National Bank of Abu Dhabi, First Gulf Bank, HSBC and Standards Charter making up the remainder. ${ }^{60}$ In October 2016, Korea Electric Power Corporation (KEPCO) took an 18 percent equity stake in Nawah Energy Company that owns the four reactors, with ENEC, holding the remaining 82 percent. $^{61}$

In July 2010, a site-preparation license and a limited construction license were granted for four reactors at Barakah, 53 kilometres from Ruwais ${ }^{62} \mathrm{~A}$ tentative schedule published in late December 2010, and not publicly altered since, suggested that Barakah-1 would start commercial operation in May 2017 with unit 2 operating from 2018, unit 3 in 2019, and unit 4 in 2020. Construction of Barakah-1 officially started on 19 July 2012, of Barakah-2 on 28 May 2013, on Barakah-3 on 24 September 2014 and unit 4 on 30 July $2015 .{ }^{63}$ As late as October 2016, Korean press was reporting unit 1 to be still scheduled for completion by May 2017. ${ }^{64}$ In May 2017,

59 ENEC, "UAE Selects Korea Electric Power Corp, as Prime Team as Prime Contractor for Peaceful Nuclear Power”, Emirates Nuclear Energy Corporation, 27 December 2009, see https://www.enec.gov.ae/news/uae-selects-korea-electric-power-corp-as-prime-teamas-prime-contractor-fo/, accessed 22 April 2018.

60 NIW, “Kepco takes 18\% of Barakah", 21 October 2016.

61 NEI, "Kepco and Enec set up joint venture for Barakah NPP”, 25 October 2016, see http:// www.neimagazine.com/news/newskepco-and-enec-set-up-joint-venture-for-barakahnpp-5647366/, accessed 22 April 2018.

62 Arabian Business, "ENEC Welcomes Regulator's License Approval”, 11 July 2010, see http://www.arabianbusiness.com/enec-welcomes-regulator-s-licence-approvals-306150. html, accessed 22 April 2018.

63 Ibid.

64 Lee Hyo-sik, "KEPCO to operate UAE nuclear plant for 60 years", The Korean Times, 20 October 2016, see http://www.koreatimes.co.kr/www/news/biz/2016/10/123_216466. html, accessed 22 April 2018. 
ENEC announced it had "completed initial construction activities for Unit 1" and the "handover of all systems for commissioning"; the plant as a whole would be 81 percent complete, with Barakah-1 at 95 percent finished. At the same time, ENEC stated: "The timeline includes an extension for the start-up of nuclear operations for Unit 1, from 2017 to 2018, to ensure sufficient time for international assessments and adherence to nuclear industry safety standards, as well as a reinforcement of operational proficiency for plant personnel."65 In March 2018, the extent of the delay was confirmed with Nawah reporting that the startup of Unit 1 would only be in $2019 .{ }^{66}$ But only a few months later, in July 2018, a new delay was announced, so that startup would be in late 2019 or early $2020^{67}$, so that commercial operation would not be undertaken until 2020, three years behind schedule.

The UAE released a long-term energy plan in February 2017, which proposes that by 2050 renewable energy will provide 44 percent of the country's electricity, with natural gas 38 percent, "clean fossil fuels" 12 percent and nuclear six percent. ${ }^{68}$ The nuclear share is in line with expected output from the Barakah nuclear power plant, so it seems that no further nuclear power plants are envisaged at this point. In September 2017, Government officials confirmed that there were no plans to build a second plant. ${ }^{69}$

65 ENEC, "ENEC Announces Completion of Initial Construction Work for Unit 1 of Barakah Nuclear Energy Plant \& Progress Update Towards Safety-led Operations”, Emirates Nuclear Energy Corporation, 5 May 2017, see https://www.enec.gov.ae/enecannounces-completion-of-initial-construction-work-barakah-unit-1-progress-update/, accessed 22 April 2018.

66 Nawah, "Next phase of preparations for Barakah Unit 1 Nuclear Operations starts" (Press Release), 28 May 2018, see http://www.nawah.ae/en/news/NextphaseofpreparationsforBarakah.html, accessed 29 May 2018.

67 Arabian Business, "UAE further delays launch of first nuclear reactor", 4 July 2018, see https://www.arabianbusiness.com/energy/400041-uae-further-delays-launch-of-first-nuclear-reactor, accessed 8 July 2018.

68 LeAnne Graves, "UAE Energy Plan aims to cut CO2 emissions $70 \%$ by 2050 ", The National, 10 January 2017, see https:/www.thenational.ae/uae/uae-energy-plan-aimsto-cut-co2-emissions-70-by-2050-1.51582, accessed 22 April 2018.

69 Amena Bahr, "UAE Abu Dhabi Unlikely to Build a Second Nuclear plant", Nuclear Intelligence Weekly, 29 September 2017. 


\section{Contracts signed}

\section{Egypt}

In Egypt, the government's Nuclear Power Plants Authority was established in the mid-1970s, and plans were developed for 10 reactors by the end of the century. Little development occurred for several decades. Then, in February 2015, Russia's Rosatom and Egypt's Nuclear Power Plant Authority eventually did sign an agreement that was expected to lead to the construction and financing of two reactors and possibly two additional ones. In November 2015, an intergovernmental agreement was signed for the construction of four VVER-1200 reactors at Dabaa, $130 \mathrm{~km}$ northwest of Cairo. In May 2016, it was announced that Egypt concluded a US\$25 billion loan with Russia for nuclear construction. ${ }^{70}$ According to the Egyptian official journal, the loan is to cover 85 percent of the project cost, with the total investment thus estimated at around US\$29.4 billion.

In December 2017, Rosatom Director General Alexey Likhachov and Mohamed Shaker, Egypt's Energy Minister signed a notice to proceed with construction as well as an agreement that "spans the power plant's entire life cycle, i.e. 70 to 80 years" ${ }^{71}$ The total cost of the project was now reported to be US\$60 billion, of which US\$30 billion for the reactor construction. Three other deals were signed to cover the supply of nuclear fuel for 60 years, operation and maintenance for the first 10 years of operation and operating and training of personnel. ${ }^{72}$ Russia would supply a loan of US\$25 billion, at three percent interest for 85 percent of the construction cost. The Egyptian government agreed to pay back over 22 years starting in 2029. The next two and half years will focus on site preparation and licensing. With construction expected to take five years, the completion of the project is now expected in $2026 / 27 .^{73}$

70 Asma Alsharif, “Russia to lend Egypt \$25 billion to build nuclear power plant”, Reuters, 1 May 2016, see http://www.reuters.com/article/us-egypt-russia-nuclearidUSKCNOYA1G5, accessed 23 May 2016.

71 WNN, “Notice to proceed' contracts signed for El Dabaa”, 11 December 2017, see http://www.world-nuclear-news.org/NN-Notice-to-proceed-contracts-signed-for-ElDabaa-1112178.html, accessed 24 April 2018.

72 Phil Chaffee, “Rosatom Locks in $\$ 30$ Billion Nuclear Deal in Egypt”, NIW, 15 December 2017.

73 Dan Yurman, “Egypt's \$60 Billion Bet on Nuclear Energy”, The Energy Collective, 23 April 2018, see https://theenergycollective.com/dan-yurman/2431718/egypts-60-billionbet-on-nuclear-energy, accessed 24 April 2018. 


\section{Turkey}

Besides Akkuyu (see above), Turkey has two other nuclear projects under development - Sinop and İğneada.

Sinop is on Turkey's northern coast and is planned to host a $4.4 \mathrm{GW}$ power plant of four units of the ATMEA reactor-design. If completed this would be the first reactors of this design, jointly developed by Japanese Mitsubishi and French AREVA..$^{74}$ In April 2015, Turkish President Erdogan approved parliament's ratification of the intergovernmental agreement with Japan. ${ }^{75}$

The estimated cost of the project was initially US $\$ 22$ billion and involved a consortium of Mitsubishi, AREVA NP (now known again as Framatome), GDF-Suez (now known as Engie), and Itochu, who between them would own 51 percent of the project, with the remaining 49 percent owned by Turkish companies including the State-owned electricity generating company EÜAS. ${ }^{76}$

The division between the international partners remains in fact undecided. The ongoing financial problems of new-old Framatome after the absorption by EDF are affecting its ability to invest in the project, as does the review by Engie of its involvement in nuclear projects across its portfolio. Furthermore, concerns remain about site suitability given its seismic conditions. ${ }^{77}$

In March 2018, reports from Japan suggest that the expected cost of the project has doubled and is now expected to be US $\$ 37.5$ billion and that it would be difficult to see completion by $2023 .^{78}$ Then in April 2018, press reports from Japan suggested that Itochu would no longer be willing to participate due to the exploding cost estimates, which have risen to more than JPY5,000 billion (US $\$ 46.2$ billion) from JPY2,000 billion (US $\$ 19$ billion) in 2013. ${ }^{79}$

74 WNN, “Turkish utility eyes large stake in Sinop project”, 12 May 2015, see http://www. world-nuclear-news.org/C-Turkish-utility-eyes-large-stake-in-Sinop-project-12051501. html, accessed 22 April 2018.

75 WNN, “Ground broken for Turkey's first nuclear power plant”, 15 April 2015, see http:// www.world-nuclear-news.org/NN-Ground-broken-for-Turkeys-first-nuclear-powerplant-1541501.html, accessed 22 April 2018.

76 WNN, “Turkish Utility Eyes Large Stake in Sinop Project”, op.cit.

77 NIW, “Akkuyu's Prospects Pull Past Sinop”, 22 July 2016.

78 Yasuaki Oshika, "Japan's nuclear export to Turkey in doubt as costs estimate doubles", The Ssahi Shimbun, 15 March 2018, see http://www.asahi.com/ajw/articles/AJ201803150046. html, accessed 22 April 2018.

79 NEI, “Japan's Itochu pulls out of Turkish nuclear project - Nuclear Engineering International", see http://www.neimagazine.com/news/newsjapans-itochu-pulls-out-of-turkish-nuclear-project-6133206, accessed 15 May 2018. 
In October 2015, the Turkish government suggested it was aiming to build a third nuclear power plant, at the İğneada site. The most likely constructors would be Westinghouse and the Chinese State Nuclear Power Technology Corporation (SNPTC). Chinese companies are said to be "aggressively" pursuing the contract, reportedly worth US\$22-25 billion. ${ }^{80}$ In September 2016, China and Turkey signed a nuclear co-operation agreement, a similar mechanism used to develop the other nuclear projects in the country. ${ }^{81}$ However, the financial collapse of Westinghouse, makes their current involvement in the project unlikely.

\section{Vietnam}

A decision by the Prime Minster of Vietnam of July 2011 stated that by 2020 the first nuclear power plant will be in operation, with a further $7 \mathrm{GW}$ of capacity to be in operation by 2025 and total of $10.7 \mathrm{GW}$ in operation by 2030. In October 2010, Vietnam had signed an intergovernmental agreement with Russia's Atomstroyexport to build the Ninh Thuan-1 nuclear power plant, using 1200 MW VVER reactors. Construction was slated to begin in 2014. However, numerous delays have occurred and the national electricity development plan, approved by the government in March 2016, envisioned the "first nuclear power plant put into operation in 2028". ${ }^{82}$ Vietnam's nuclear power ambitions were severely curtailed in November 2016, when 92 percent of the members of the National Assembly approved a government motion to cancel the proposed nuclear projects with both Russia and Japan, due to slowing electricity demand increases, concerns of safety and rising construction costs. ${ }^{83}$

80 NEI, “Turkey finalizes site for third NPP”, 18 March 2016, see http://www.neimagazine. com/news/newsturkey-finalizes-site-for-third-npp-4843161/, accessed 26 April 2017.

81 Herguner Ozeke, “Turkey Looks to China for Third Nuclear Power Plant”, Lexology, 3 January 2018, see https://www.lexology.com/library/detail.aspx?g=d0b6672d-14e143d0-a5b3-c9750552f521, accessed 22 April 2018.

82 VietNamNet, "Vietnam needs US $\$ 148$ billion to develop national electricity until 2030", 20 March 2016, see http://english.vietnamnet.vn/fms/society/152739/vietnam-needs-us-148-billion-to-develop-national-electricity-until-2030.html, accessed 22 April 2018.

83 NIW, “Briefs - Vietnam”, 28 November 2016. 


\section{"Committed plans"}

\section{Lithuania}

Lithuania had two large RBMK (Chernobyl-type) reactors at Ignalina, which were shut down in 2004 and 2009, a requirement for joining the European Union. Since then there have been ongoing attempts to build a replacement, either unilaterally or with neighbouring countries. However, in October 2012, a consultative national referendum on the future of nuclear power was held and 63 percent voted against new nuclear construction, with sufficient turnout to validate the result. ${ }^{84}$ Prior to his appointment as Prime Minister, Algirdas Butkevicius stated that legislation prohibiting the project would be submitted once the new parliament convenes and that "the people expressed their wish in the referendum, and I will follow the people's will" ${ }^{85}$ In early 2016, the Energy Minister of Lithuania, Rokas Masiulis, said that the project had been shelved indefinitely, due to unfavorable market conditions. ${ }^{86}$

\section{Jordan}

Influential policy makers in Jordan have long desired the acquisition of a nuclear power plant. In 2007, the government established the Jordan Atomic Energy Commission (JAEC) and the Jordan Nuclear Regulatory Commission. JAEC started conducting a feasibility study on nuclear power, including a comparative cost/benefit analysis. ${ }^{87}$ And in September 2014, JAEC and Rosatom signed a two-year development framework for a project, which was estimated to cost under US $\$ 10$ billion and generate electricity costing US $\$ 0.10 / \mathrm{kWh} .{ }^{88}$ After lengthy unfruitful negotiations, in May 2018, an unnamed government official revealed to The Jordan Times that the plan to build two $1000 \mathrm{MW}$ "is now over", and that "Jordan is now focusing on small modular reactors". ${ }^{89}$ This was confirmed the following month by the Jordan

84 Christian Lowe, "Lithuanians send nuclear plant back to drawing board", Reuters, 15 October 2012, see http://www.reuters.com/article/us-lithuania-nuclear-idUSBRE89E0BW20121015, accessed 22 April 2018.

85 NIW, "Lithuania-Prospective PM Wants to Scrape Visaginas", 9 November 2012.

86 The Baltic Course, "Masiulis: Visaginas NPP project has been shelved for now", 20 January 2016, see http://www.baltic-course.com/eng/energy/?doc=115564, accessed 22 April 2018.

87 Mark Hibbs, "Jordan reactor siting study to be done in 2009, JAEC says", Nucleonics Week, 27 September 2007.

88 NIW, “Briefs - Jordan”, 18 April 2014.

89 Mohammad Ghazal, "Jordan to replace planned nuclear plant with smaller, cheaper facility”, Jordan Times, 26 May 2018, see http://www.jordantimes.com/news/local/ jordan-replace-planned-nuclear-plant-smaller-cheaper-facility, accessed 1 June 2018. 
Atomic Energy Commission. The development suggests not only that Jordan was unable to secure financing for the two $1000 \mathrm{MW}$ proposal, but also that Russia was unable to provide low-interest financing.

In the last couple of years, JAEC has signed a series of MOUs and agreements on SMRs..$^{90}$ The most recent announcement to come from JAEC Chairman Toukan, in April 2018, is that the organization is in "serious and advanced" talks with China National Nuclear Corporation (CNNC) to build a 220 MW High Temperature GasCooled Reactor (HTR) in Jordan. ${ }^{91}$ Although SMRs could be cheaper in terms of total cost, they are expected to be more expensive on a per-MW basis and would pose a range of problems such as siting. ${ }^{92}$

\section{Poland}

Poland planned the development of a series of nuclear power stations in the 1980s and started construction of two VVER1000/320 reactors in Żarnowiec on the Baltic coast, but both construction and further plans were halted following the Chernobyl accident. However, on 28 January 2014, the Polish Government adopted a document with the title "Polish Nuclear Power Programme" outlining the framework of the strategy. The plan includes proposals to build $6 \mathrm{GW}$ of nuclear power capacity with the first reactor starting up by $2024 .{ }^{93}$

In January 2013, the Polish utility PGE (Polska Grupa Energetyczna) had selected WorleyParsons to conduct a five-year, US $\$ 81.5$ million study, on the siting and development of a nuclear power plant with a capacity of up to $3 \mathrm{GW} \cdot{ }^{94}$ At that time, the project was estimated at US $\$ 13-19$ billion, site selection was to have been

90 WNN, "Jordan to consider deployment of X-energy SMR", 29 November 2017, see http://www.world-nuclear-news.org/NN-Jordan-to-consider-deployment-of-X-energySMR-2911175.html, accessed 24 April 2018; "Russian Sweep in the Middle East", NIW, 15 December 2017.

91 Mohammad Ghazal, “Jordan, China in 'serious talks' to build gas-cooled \$1b reactor”, Jordan Times, 28 April 2018, see http://ftp.jordantimes.com/news/local/jordan-chinaserious-talks\%E2\%80\%99-build-gas-cooled-1b-reactor, accessed 8 May 2018.

92 M.V. Ramana and Ali Ahmad, "Wishful Thinking and Real Problems: Small Modular Reactors, Planning Constraints, and Nuclear Power in Jordan”, Energy Policy, 26 March 2016.

93 Lukasz Kuzniarski, "Polish Nuclear Power Programme”, Ministry of Economy, 17 March 2014, see https://www.iaea.org/NuclearPower/Downloadable/Meetings/2014/201403-17-03-21-WS-INIG/DAY2/COUNTRY/L_Kuzniarski_POLAND_IAEA_workshop_Seoul_2014.pdf, accessed 24 April 2018.

94 NIW, "Briefs-Poland”, 8 February 2013. 
completed by 2016, and construction was to begin in $2019 .{ }^{95}$ However, financing remained a key barrier. And in December 2017, the rating agency Fitch, warned that "if the utilities decide to get involved in building the nuclear power plant and put it on their balance sheets then certainly we will have a close look as this may be negative for the ratings." This is because Polish utilities are already "substantially leveraged" and the massive cost of nuclear investment would be problematic. Furthermore, the agency suggested that offshore wind, with falling technology costs would be more economic. ${ }^{96}$

In late 2017, the Energy Minister, Krzysztof Tchorzewski, said that he would like to see Poland build three nuclear reactors, at five-yearly intervals, the first to operate in 2029, with each unit costing US $\$ 7$ billion. ${ }^{97}$ The Government, in January 2018, announced that it would decide during the year, if it did proceed with nuclear power, with a decision "definitely, in the first half"..$^{98}$ That did not happen.

\section{Conclusion on potential newcomer countries}

The history of potential nuclear newcomer countries is a history of delays, cost estimate increases and abandoned projects before they even get started on the ground. While construction is under way in Bangladesh, Belarus, Turkey and the UAE, projects have been suspended or cancelled in most of the other candidate countries. Two countries, Egypt and Saudi Arabia, both in the Middle East, appear to have made some progress in the deployment of nuclear power but the next few years will determine whether this will result in the actual commencement of construction.

95 Economist, "Polish Energy, Going nuclear", 31 January 2014, see http://www.economist. com/blogs/easternapproaches/2014/01/polish-energy, accessed 24 April 2018.

96 Reuters, "Funding nuclear project could hit Polish utilities' ratings: Fitch", 8 December 2017, see https://www.reuters.com/article/us-poland-nuclear/funding-nuclear-project-could-hit-polish-utilities-ratings-fitch-idUSKBN1E21YM accessed 30 June 2018.

97 Reuters, "Poland may have first nuclear power plant by 2029", 6 September 2017, see https://www.reuters.com/article/poland-nuclear/poland-may-have-first-nuclear-powerplant-by-2029-idUSL8N1LN222, accessed 24 April 2018.

98 Reuters, "Poland to decide later this year on building nuclear plant | Reuters", 29 January 2018, see https://www.reuters.com/article/us-poland-nuclear/poland-to-decide-laterthis-year-on-building-nuclear-plant-idUSKBN1FI1Q8, accessed 30 June 2018. 
Tab.3 Summary of Potential Nuclear Newcomer Countries

\begin{tabular}{|c|c|c|c|c|c|}
\hline & Site & $\begin{array}{l}\text { Proposed } \\
\text { Vendor }\end{array}$ & $\begin{array}{c}\text { Initial } \\
\text { Startup Date }\end{array}$ & $\begin{array}{c}\text { Proposed } \\
\text { Construction } \\
\text { Start }\end{array}$ & \\
\hline \multicolumn{6}{|c|}{ Under Construction } \\
\hline Bangladesh & Rooppur & Rosatom & Nov 2017 & April 2018 & 2023 \\
\hline Belarus & Ostrovets & Rosatom & $2016 / 18$ & & $\begin{array}{c}2019(\mathrm{Q} 4) / 2020 \\
\text { (Q3) }\end{array}$ \\
\hline Turkey & Akkuyu & Rosatom & 2015 & 2018 & 2023 \\
\hline UAE & Barakah & KEPCO & $2017 / 18 / 19 / 20$ & & $2019 / 2020$ \\
\hline \multicolumn{6}{|c|}{ Contract Signed or Advanced Development } \\
\hline Lithuania & Visegrade & Hitachi & 2020 & Suspended & - \\
\hline Turkey & Sinop & $\begin{array}{c}\text { Mitsubishi/ } \\
\text { Areva }\end{array}$ & & $?$ & - \\
\hline & Ingeada & $\begin{array}{l}\text { SNPTC/ } \\
\text { Westing- } \\
\text { house }\end{array}$ & & 2019 & - \\
\hline Vietnam & Ninh Thuan & Rosatom & 2020 & Suspended & - \\
\hline \multicolumn{6}{|c|}{ Committed Plans } \\
\hline Egypt & & Rosatom & 2019 & 2018 & $2026 / 2027$ \\
\hline Jordan & & Rosatom & & 2019 & 2024 \\
\hline Poland & & & & $?$ & 2029 \\
\hline \multicolumn{6}{|c|}{ Well Developed Plans } \\
\hline Chile & & & 2024 & Suspended & - \\
\hline Indonesia & & Rosatom & & $\begin{array}{l}\text { Indefinitely } \\
\text { Postponed }\end{array}$ & - \\
\hline Kazakhstan & & $\begin{array}{l}\text { Rosatom } \\
\text { or Wes- } \\
\text { tinghouse }\end{array}$ & & $?$ & - \\
\hline Saudi Arabia & & & 2020 & $?$ & 2027 \\
\hline Thailand & & & $2020-8$ & $?$ & - \\
\hline
\end{tabular}

Sources: Various, compiled by WNISR, 2018 


\section{General conclusions}

The global nuclear industry is struggling with a combination of factors that severely impact its competitiveness. The continuous ageing of the reactor fleet induces longer maintenance outages and costlier upgrades. In many wholesale markets, the price-level is lower than the operating and maintenance costs of amortized reactors. The incumbent nuclear utilities are facing ferocious competition from new players that enter the market following sector liberalization measures. For example, the largest nuclear operator in the world, the French EDF, is losing 100,000 clients per month. In the U.S., many uneconomic reactors are only surviving on the grid with massive direct subsidies on state level. While nuclear generating costs are increasing, costs of competing technologies, in particular solar, wind and natural gas, have been falling dramatically over the past decade. It has turned out impossible to build a new nuclear power plant under market economy conditions and massive government support is indispensable. But even then, the nuclear industry is suffering from excessively long lead times compared to its competitors. So the renewal rate of the fleet is below the minimum necessary for survival. Nuclear power is turning into an endangered species that, in addition, is increasingly threatened by an invasive species, cheap and abundant renewables.

Open Access This chapter is licensed under the terms of the Creative Commons Attribution 4.0 International License (http://creativecommons.org/licenses/by/4.0/), which permits use, sharing, adaptation, distribution and reproduction in any medium or format, as long as you give appropriate credit to the original author(s) and the source, provide a link to the Creative Commons license and indicate if changes were made.

The images or other third party material in this chapter are included in the chapter's Creative Commons license, unless indicated otherwise in a credit line to the material. If material is not included in the chapter's Creative Commons license and your intended use is not permitted by statutory regulation or exceeds the permitted use, you will need to obtain permission directly from the copyright holder.

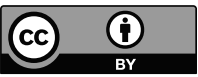

